\title{
A whole-tree chamber system for examining tree-level physiological responses of field-grown trees to environmental variation and climate change
}

\author{
JANE MEDHURST ${ }^{1}$, JAN PARSBY ${ }^{2}$, SUNE LINDER $^{3}$, GÖRAN WALLIN $^{4}$, ERIC CESCHIA $^{5}$ \& MICHELLE SLANEY ${ }^{3}$ \\ ${ }^{1}$ University of Tasmania, CRC Forestry, Private Bag 12, Hobart, TAS 7001 Australia, ${ }^{2}$ The Phytotron, Swedish University of \\ Agricultural Sciences (SLU), PO Box 7027, SE-750 07 Uppsala, ${ }^{3}$ Southern Swedish Forest Research Centre, SLU, PO Box 49, \\ SE-230 53 Alnarp, ${ }^{4}$ Department of Plant and Environmental Sciences, University of Göteborg, PO Box 461, SE-405 30 \\ Göteborg, Sweden, and ${ }^{5}$ CESBIO, 18 Avenue Edouard Belin, 31401 Toulouse, Cedex 9, France
}

\begin{abstract}
A whole-tree chamber (WTC) system was installed at Flakaliden in northern Sweden to examine the long-term physiological responses of field-grown 40-year-old Norway spruce trees [Picea abies (L.) Karst.] to climate change. The WTCs were designed as large cuvettes to allow the net tree-level $\mathrm{CO}_{2}$ and water fluxes to be measured on a continuous basis. A total of 12 WTCs were used to impose combinations of atmospheric carbon dioxide concentration, $\left[\mathrm{CO}_{2}\right]$, and air temperature treatments. The air inside the ambient and elevated [CO $\left.\mathrm{CO}_{2}\right]$ WTCs was maintained at 365 and $700 \mu \mathrm{mol} \mathrm{mol}^{-1}$, respectively. The air temperature inside the ambient temperature WTCs tracked air temperature outside the WTCs. Elevated temperatures were altered on a monthly time-step and ranged between +2.8 and $+5.6{ }^{\circ} \mathrm{C}$ above ambient temperature. The system allowed continuous, long-term measurement of whole-tree photosynthesis, night-time respiration and transpiration. The performance of the WTCs was assessed using winter and spring data sets. The ability of the WTC system to measure tree-level physiological responses is demonstrated. All WTCs displayed a high level of control over tracking of air temperatures. The set target of $365 \mu \mathrm{mol} \mathrm{mol}^{-1}$ in the ambient $\left[\mathrm{CO}_{2}\right]$ chambers was too low to be maintained during winter because of tree dormancy and the high natural increase in $\left[\mathrm{CO}_{2}\right]$ over winter at high latitudes such as the Flakaliden site. Accurate control over $\left[\mathrm{CO}_{2}\right]$ in the ambient $\left[\mathrm{CO}_{2}\right]$ chambers was restored during the spring and the system maintained the elevated $\left[\mathrm{CO}_{2}\right]$ target of $700 \mu \mathrm{mol} \mathrm{mol}^{-1}$ for both measurement periods. Air water vapour deficit (VPD) was accurately tracked in ambient temperature WTCs. However, as water vapour pressure in all 12 WTCs was maintained at the level of nonchambered (reference) air, VPD of elevated temperature WTCs was increased.
\end{abstract}

Key-words: Picea abies; elevated air temperature; elevated $\mathrm{CO}_{2}$; gas exchange; Norway spruce.

Correspondence: Jane Medhurst. Fax: +6136226 7942; e-mail: jane.medhurst@utas.edu.au

\section{INTRODUCTION}

Global carbon dioxide concentration $\left(\left[\mathrm{CO}_{2}\right]\right)$ increased from 280 to $365 \mu \mathrm{mol} \mathrm{mol}^{-1}$ between the years 1800 and 2000 (IPCC 2001). The increase in $\left[\mathrm{CO}_{2}\right]$ is predicted to continue, with possible concentrations of $700 \mu \mathrm{mol} \mathrm{mol}^{-1}$ by the year 2100 (IPCC 2001). Concomitant with this rise in global $\left[\mathrm{CO}_{2}\right]$ is predicted increases in mean surface temperatures in the order of $2-6{ }^{\circ} \mathrm{C}$ (Burroughs 2001). The greatest warming is expected to be at northern high latitudes (IPCC 2001). The response of the large tracts of forest at these latitudes to climate change may be pivotal in determining the future extent to which forests act as net global sinks for atmospheric carbon. Accurate measurements of tree photosynthesis, respiration and transpiration under the predicted future climate are invaluable for understanding and modelling forest-ecosystem carbon exchange and storage. Such measurements rely on systems that provide environmental control and are able to mimic global climate change.

Our understanding of plant functioning and response to changing growth conditions has been greatly advanced by the application of environmental engineering in addressing physiological questions. Engineering designs that both control the growth environment and measure tree responses are particularly useful for examining the effects of exposure to atmospheric pollutants. A range of plant exposure systems have been employed over the last two decades, with noted success in shorter crop species (Allen et al. 1992). A new set of challenges arises when attempting to expose large trees and forest ecosystems to increased $\left[\mathrm{CO}_{2}\right]$. Approaches have included branch bags (Barton, Lee \& Jarvis 1993; Kellomäki \& Wang 1997; Saugier et al. 1997; Robertnz 1999), open-top chambers (e.g. Whitehead et al. 1995; Jach \& Ceulemans 1999; Murray et al. 2000), opensided chambers (Liozon et al. 2000), glass domes with adjustable windows (Urban et al.2001), free air $\mathrm{CO}_{2}$ enrichment (FACE) systems (e.g. Hendrey et al. 1999; Hamilton, Thomas \& DeLucia 2001; Herrick \& Thomas 2001; Körner et al. 2005) and closed-top chambers (Kellomäki, Wang \& Lemettinen 2000). Each of these systems has a particular set of advantages and disadvantages (see review by Saxe, 
Ellsworth \& Heath 1998). Hence, the choice of system design is a critical first step in addressing any questions regarding tree response to climate change. A closed-top whole-tree chamber (WTC) system was considered to be the best approach for examining the medium to long-term effect of climate change on the functioning of boreal forest ecosystems.

The WTC system presents a number of advantages. It is a field-based system that utilizes mature trees. In this respect there are no root constrictions as with pot-based experiments, which with time can restrict root growth and lower the carbon sink strength of the plant. Root constriction has been linked to the observed down-regulation of photosynthetic capacity following $\left[\mathrm{CO}_{2}\right]$ enrichment (e.g. Drake, Gonzàlez-Meler \& Long 1997). There is, however, conflicting evidence as to whether photosynthetic downregulation occurs in mature forest trees growing under elevated $\left[\mathrm{CO}_{2}\right]$ (Curtis 1996), highlighting the need to examine this phenomenon using field-grown trees (cf. Körner 2003; Luo et al. 2004; Norby \& Luo 2004). The responses of mature trees to $\left[\mathrm{CO}_{2}\right]$ and temperature elevation are also likely to differ with ontogeny (Saxe et al. 1998, 2001). By exposing whole trees to elevated $\left[\mathrm{CO}_{2}\right]$, the WTC system enables the responses of mature trees to be examined. The design of the WTC system allows for both the (1) application of $\left[\mathrm{CO}_{2}\right]$ and temperature treatments and (2) longterm, continuous measurement of tree-level responses (photosynthesis, respiration and transpiration) to those treatments. The uncertainty associated with scaling seedling or leaf-level responses to estimate the response at the mature tree level is thus eliminated. As the WTC system is an enclosed system, precise control of temperature and humidity is possible. This is an advantage over branch bags and open-top chambers (OTCs), which require high volume air flows to counteract uncontrolled temperature increases (Robertnz \& Stockfors 1998). This is an important consideration, given that increases in $\left[\mathrm{CO}_{2}\right]$ are accompanied by increases in surface air temperatures (IPCC 2001). The ability of the WTC system to control temperature allows the physiological responses of mature trees to elevated $\left[\mathrm{CO}_{2}\right]$ and temperature to be examined singly and in combination. There are, however, possible chamber effects on leaf morphology and crown structure resulting from the absence of exposure to rainfall and snowfall, the potential for protection from radiation frosts, and the possible changes in light interception and reflection.

This paper describes a WTC system at the Flakaliden research site in northern Sweden. The system was used in a first experiment to examine interactions between elevated $\left[\mathrm{CO}_{2}\right]$ and nutrient and water availability (cf. Ceschia 2001; Fransson, Taylor \& Finlay 2001; Kostiainen et al. 2004) and subsequently in a second experiment used to impose elevated $\left[\mathrm{CO}_{2}\right]$ and temperature treatments on 40-year-old field-grown Norway spruce trees (cf. Comstedt et al. 2006; Slaney 2006; Slaney et al. in review). In addition to the system description, the ability of the system in providing accurate environmental control is examined and some examples of tree net $\mathrm{CO}_{2}$ flux in response to environmental variation are presented. For this description, data from the second experiment was used.

\section{MATERIALS AND METHODS}

\section{Site description}

The WTCs were installed in a 40-year-old Norway spruce [Picea abies (L.) Karst.] plantation at the Flakaliden research site in northern Sweden $\left(64^{\circ} 07^{\prime} \mathrm{N} 19^{\circ} 27^{\prime} \mathrm{E}\right)$, where a nutrient-optimization experiment had commenced in 1987 (Linder 1995; Bergh et al. 1999). Norway spruce is one of the main tree species of the boreal forest regions of northern Europe, which meant that Flakaliden was a suitable location for examining the responses of boreal forest ecosystems to elevated temperature and $\left[\mathrm{CO}_{2}\right]$ levels. The Flakaliden research site was also ideal as it had existing infrastructure required for such a project (e.g. main electricity supply, irrigation system), as well as for a long-term monitoring of tree growth in relation to weather and soil nutrient availability.

The annual mean temperature at the site is $2.3^{\circ} \mathrm{C}$ and the monthly mean air temperature varies from $-7.3^{\circ} \mathrm{C}$ in January to $14.6^{\circ} \mathrm{C}$ in July (mean for the period $\left.1990-2004\right)$. Mean annual rainfall is $600 \mathrm{~mm}$, with approximately onethird falling as snow, which usually covers the frozen ground from mid-October to early May (Stockfors \& Linder 1998a). The length of the vegetation period (average temperature $\geq+5^{\circ} \mathrm{C}$ ) is $135 \mathrm{~d}$ (Bergh et al. 1999). The soil at Flakaliden is a podzolic, glacial, loamy till with an average depth of approximately $1.2 \mathrm{~m}$ and an average humus layer depth of 30-40 mm (Bergh \& Linder 1999).

\section{Experimental design}

The WTC system has been used in two experiments where 12 WTCs were installed around individual trees. In a third experiment, commencing in 2006, the WTC system will be used to investigate the interactions between soil water availability and elevated $\left[\mathrm{CO}_{2}\right]$ in Eucalyptus trees (The Hawkesbury Forest Experiment, NSW, Australia). In the first experiment (1997-2000), the WTC system was used to study the effect of elevated $\left[\mathrm{CO}_{2}\right]$ in combinations with a fertilizer and irrigation treatment. In the second experiment (20012004), which most of this paper is based on, the WTCs were installed in an untreated control plot that had received no previous treatment. A combination of two temperature levels $\left(\mathrm{T}_{\mathrm{A}}\right.$, ambient and $\mathrm{T}_{\mathrm{E}}$, elevated $)$ and two $\left[\mathrm{CO}_{2}\right]$ levels $\left(\mathrm{C}_{\mathrm{A}}\right.$, ambient $365 \mu \mathrm{mol} \mathrm{mol}^{-1}$ and $\mathrm{C}_{\mathrm{E}}$, elevated $700 \mu \mathrm{mol} \mathrm{mol}^{-1}$ ) was used as treatment variables in the WTCs and was arranged in a $2 \times 2$ factorial design. Three reference (R) trees without WTCs were also randomly selected and in total 15 trees were assigned to five treatments $\left(\mathrm{T}_{\mathrm{A}} \mathrm{C}_{\mathrm{A}}, \mathrm{T}_{\mathrm{E}} \mathrm{C}_{\mathrm{A}}, \mathrm{T}_{\mathrm{A}} \mathrm{C}_{\mathrm{E}}\right.$, $\left.\mathrm{T}_{\mathrm{E}} \mathrm{C}_{\mathrm{E}}, \mathrm{R}\right)$. This design allowed us to make (1) a two-way analysis of variance (ANOVA) for the chamber treatments, (2) an unpaired Student's $t$-test of the R trees compared with any chamber treatment, or (3) a one-way ANOVA for all five treatments followed by a post hoc test (e.g. Tukey's honestly 
significant difference test) to identify which of the treatments are statistically different from each other.

\section{Description of the WTC system}

\section{Chamber construction}

The WTCs were modular in design and consisted of three main sections; the chamber base (soil compartment), the tree chamber (above-ground compartment) and the cooling unit (Fig. 1). The base section was approximately $0.4 \mathrm{~m}$ in height. The circular base frame was, like all other chamber sections, constructed from aluminium and was $3.25 \mathrm{~m}$ in diameter. The wall of the base section was sealed with a sleeve of $0.4 \mathrm{~mm}$ transparent polyvinyl chloride (PVC) film (Renolit AB, Worms, Germany). The base of the sleeve was covered with soil to provide a seal between the base and the ground. The top of the chamber base was sealed with a combination of the $0.4 \mathrm{~mm}$ PVC film and transparent Perspex sheets (Röhm Plexiglas, Dusseldorf, Germany) of $5 \mathrm{~mm}$ thickness. The base was sealed around the tree stem to prevent air exchange between the soil compartment and the tree chamber. A small Perspex trapdoor $(700 \times 850 \mathrm{~mm})$ allowed access to the soil under the chamber base. The trapdoor was sealed and securely screwed to the base frame when not in use. Two microsprinklers (Agridor Ltd., Rosh Ha'ayin, Israel), connected to an irrigation system, were installed under the chamber floor on $0.3 \mathrm{~m}$ spikes so that the trees could be irrigated with the same amount of water that was measured by rain gauges outside the WTCs. Each sprinkler could deliver $60 \mathrm{~L} \mathrm{~h}^{-1}$.

To allow any soil disturbances to subside, the base frames and bottom sections were installed in September 2000, eight months before the rest of the chamber sections were mounted. Wooden walkways were constructed around and between each base to prevent soil compaction. Fresh air was continuously drawn through the chamber base using a shielded $125 \mathrm{~mm}$ air inlet and an extraction fan. Air was circulated around the chamber base by a fan (Model TD160, Soler \& Palau, Barcelona, Spain) at a flow of $160 \mathrm{~m}^{3} \mathrm{~h}^{-1}$. A shielded thermistor was attached to this fan for measurement of air temperature inside the chamber base and another thermistor was placed in the soil at a depth of $100 \mathrm{~mm}$. Soil moisture at a depth of $150 \mathrm{~mm}$ was continuously monitored with a single soil moisture sensor (Thetaprobe ML1, Delta-T Devices Ltd, Cambridge, UK) placed under the floor of each WTC.

The frame of the tree chamber section was also covered with transparent PVC film $(0.4 \mathrm{~mm})$. The tree chamber was composed of two sections, a 2.5-m-high bottom section and a top section which was conical in shape and had a height of $3.0 \mathrm{~m}$. To keep pace with tree height growth, the modular design allowed for additional cylindrical sections to be added between the bottom and top sections.

A safety ventilation system was designed to circulate fresh air through the chamber in the event of a power failure or refrigeration unit malfunction. Two circular air inlets were installed in the chamber, one at the base of the tree chamber

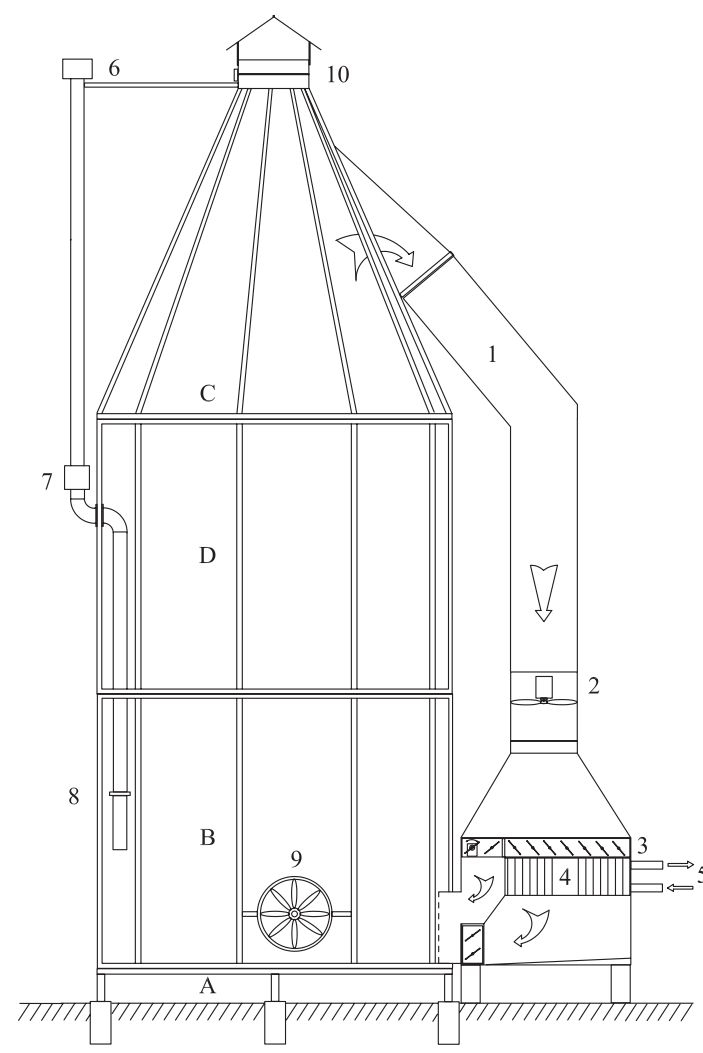

Figure 1. Schematic diagram of a whole-tree chamber (WTC) used in the long term manipulation experiments at Flakaliden. The modular chamber design consisted of three main components: the chamber base (soil compartment), the tree chamber (aboveground compartment) and a cooling unit placed directly outside the chamber. The diameter of the WTC was $3.25 \mathrm{~m}$. The chamber base (A) was approximately $0.4 \mathrm{~m}$ high. The tree chamber consisted of a bottom (B) and a top (C) section, with a height of $2.5 \mathrm{~m}$ and $3.0 \mathrm{~m}$, respectively. Extra sections (D) could be added to the tree chamber to keep up with tree height growth. Some major components of the system are indicated in the diagram by numbers: (1) pipe $(\varnothing=630 \mathrm{~mm})$ for circulating chamber air through the cooling unit; (2) frequency-controlled fan (0$12000 \mathrm{~m}^{3} \mathrm{~h}^{-1}$ ); (3) dampers to regulate the amount of air going through the cooling battery; (4) large-surface cooling battery; (5) circulating a glycol/water (30/70\%) solution maintained at ambient dew point temperature; (6) fresh air inlet; (7) fan for fresh air intake; (8) iris damper for flow control of fresh air intake; (9) safety fan connected to a diesel generator which starts in case of power failure; and a $12-\mathrm{V}$ controlled safety damper working in parallel with a similar damper (10) at the top of the WTC. For further explanations, see text.

and one at the top of the conical top section. Each air inlet was $650 \mathrm{~mm}$ in diameter and was, when not in use, sealed with a metal damper. The dampers could be rotated by $90^{\circ}$ around a spindle by a motor (Model SM24, Belimo, Hinwil, Switzerland). In the event of either a power failure or the temperature inside any of the 12 chambers reaching $8{ }^{\circ} \mathrm{C}$ above ambient temperature, a relay started a diesel generator (Model YDG 3700E-E, Yanmar, Tokyo, Japan) and the dampers were opened. A ventilation fan, attached to the base vent, then forced fresh air through the chamber, from 
the bottom and out via the top vent at a rate of $2300 \mathrm{~m}^{3} \mathrm{~h}^{-1}$. In the event of normal power or temperature regulation being restored, the safety ventilation fan stopped and the safety ventilation dampers were automatically closed.

Air from the top of the chamber was drawn into the cooling unit by a powerful, frequency-controlled fan (Swegon, Kvänum, Sweden) at a rate that could be regulated between 0 and $12000 \mathrm{~m}^{3} \mathrm{~h}^{-1}$. This fan was positioned on top of the cooling unit at the base of an aluminium circulation pipe $(630 \mathrm{~mm}$ in diameter). Conditioned air was then returned from the cooling unit to the base of the tree chamber. The incoming air was deflected upwards by a curved aluminium sheet positioned at the mouth of the cooling unit. Two strategically positioned transparent Perspex sheets above the aluminium sheet facilitated the mixing of conditioned air with the remainder of the chamber air. The volume of water condensed from the conditioned air was measured at an outlet pipe at the base of the cooling unit by a tipping bucket rain gauge.

Fresh air was continuously added to the chamber via an inlet pipe of $125 \mathrm{~mm}$ diameter. A fan positioned at the midpoint of the inlet pipe drew air from above the canopy. This air passed through a regulating iris (IRIS-125, RECIndovent AB, Mölndal, Sweden) with an adjustable aperture. The iris was located $400 \mathrm{~mm}$ from the end of the fresh air inlet. The rate of airflow into the chamber was calibrated using an inflatable bag of known volume (Mätforum, Nacka, Sweden). Differential pressure measurements across the iris were made by a low pressure transducer (Model LP, Data Instruments, Acton, MA, USA). To reduce the fresh airflow, and hence the amount of $\mathrm{CO}_{2}$ and heating required to maintain treatment levels during winter, perforated caps were placed over the fresh air inlet during each winter and removed in early spring. The volumetric fresh airflow into the chambers during the winter months was approximately $42 \mathrm{~m}^{3} \mathrm{~h}^{-1}$. At other times of the year the fresh airflow was approximately $54 \mathrm{~m}^{3} \mathrm{~h}^{-1}$. The chamber internal volume (including air circulation pipe and cooling unit) was $56.3 \mathrm{~m}^{3}$.

\section{$\mathrm{CO}_{2}$ supply and control}

Pure $\mathrm{CO}_{2}$ was supplied to the WTCs from a set of 12 interconnected tanks, which contained $210 \mathrm{~kg}$ of liquefied $\mathrm{CO}_{2}$ at a pressure of 50 bar (AGA, Sundbyberg, Sweden). During the growing season, one set of tanks would supply $\mathrm{CO}_{2}$ to the WTCs for approximately 2 weeks. A pressure regulator (Model 8624, Bürket, Ingelfingen, Germany) on the $\mathrm{CO}_{2}$ line from the tanks maintained a constant $\mathrm{CO}_{2}$ pressure of 4.0 bar to the chambers. An infrared $\mathrm{CO}_{2}$ gas analyser in each chamber (SBA-1, PP Systems, Hitchin, UK) was used to measure chamber $\left[\mathrm{CO}_{2}\right]$ at $90 \mathrm{~s}$ intervals. In order to maintain chamber $\left[\mathrm{CO}_{2}\right]$ at the set target level, pure $\mathrm{CO}_{2}$ was injected into the circulating chamber air through a magnetic valve (Bürket), which opened for a programme-determined period during each $90 \mathrm{~s}$ interval. The amount of pure $\mathrm{CO}_{2}$ added to the chamber was determined from the period of time the magnetic valve was open and the mean $\mathrm{CO}_{2}$ flow rate measured in the chamber by a mass flow meter (AWM3000 and AWM5000 for $\mathrm{C}_{\mathrm{A}}$ and $\mathrm{C}_{\mathrm{E}}$ chambers, respectively, Honeywell, Freeport, IL, USA). The mass flow meter was housed in an insulated box that was thermostatically controlled at $20^{\circ} \mathrm{C}$. A copper coil on the $\mathrm{CO}_{2}$ line before the flow meter allowed the $\mathrm{CO}_{2}$ gas temperature to reach box temperature before flow measurement in each WTC. Each mass flow meter was calibrated using a piston-driven flow calibrator (DryCal DC-1, Bios International, Butler, NJ, USA).

The $\left[\mathrm{CO}_{2}\right]$ of non-chamber air (termed reference air) was continuously measured by two infrared gas analysers (IRGA); a CIRAS-2 DC (PP Systems) and a WBA-2 system (PP Systems). Reference air was drawn continuously from above the canopy using a mast erected in proximity to the WTCs. A quantum sensor (LI-190SA, Li-Cor, Lincoln, NE, USA) to measure photosynthetic photon flux density (PPFD) at 3 min intervals was also installed in this mast.

\section{Temperature control - heating and cooling}

Temperature control in each WTC was achieved by circulating the WTC air over a heat exchanger inside the cooling unit. The heat exchanger consisted of a battery of tubes $(1400 \times 960 \mathrm{~mm})$ filled with circulating glycol cooled to dew point temperature by a $150 \mathrm{~kW}$ refrigeration unit (Daikin EUV60, Daikin Industries Ltd., Osaka, Japan). The volume of circulating air that passed over the heat exchanger and the volume that bypassed the heat exchanger was controlled by a series of dampers within the cooling unit (cf. Fig. 1). The damper apertures in each WTC were adjusted by a programme-driven actuator (ASU1d15, Staefa Control, Cumming, GA, USA) at $90 \mathrm{~s}$ intervals. The adjustments maintained the air temperature within the WTC either (1) at the same air temperature outside the WTCs for $\mathrm{T}_{\mathrm{A}}$ WTCs

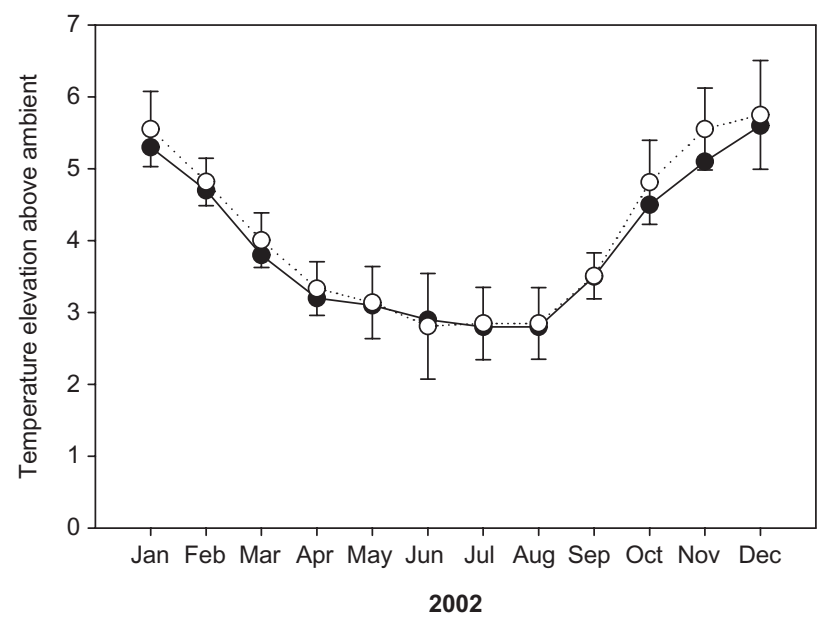

Figure 2. Monthly temperature elevations used at Flakaliden for temperature-elevated $\left(\mathrm{T}_{\mathrm{E}}\right)$ whole-tree chambers (WTCs). Target temperature elevation values (filled circles) were generated by a meteorological model (SWECLIM) using the latitude of Flakaliden and assuming $\left[\mathrm{CO}_{2}\right]$ of $700 \mu \mathrm{mol} \mathrm{mol}^{-1}$. Actual mean monthly temperature elevations for the $\mathrm{T}_{\mathrm{E}}$ WTCs (open circles) are shown for 2002. Means were calculated by pooling all $\mathrm{T}_{\mathrm{E}}$ data for each month. Error bars show \pm 1 standard deviation. $n=6$. 
or (2) at the set elevation above reference air temperature for $\mathrm{T}_{\mathrm{E}}$ WTCs (cf. Fig. 2). The air temperatures inside and outside the WTCs were measured by ventilated and shielded thermistors at a height of approximately $5 \mathrm{~m}$.

In the $\mathrm{T}_{\mathrm{E}}$ WTCs, the monthly temperature elevation was based on results from the SWECLIM modelling programme (Christensen et al. 2001; Räisänen \& Joelsson 2001; Räisänen, Rummukainen \& Ullerstig 2001) using the latitude of Flakaliden and a $\left[\mathrm{CO}_{2}\right]$ of $700 \mu \mathrm{mol} \mathrm{mol}{ }^{-1}$ (Fig. 2). The highest temperature elevation was during December $\left(+5.6{ }^{\circ} \mathrm{C}\right.$ above ambient) and the lowest was during July and August (each $+2.8^{\circ} \mathrm{C}$ above ambient). Elevated temperature regulation was achieved by a combination of (1) reducing the amount of air passing over the heat exchanger and (2) the use of two heating elements installed in the circulating air pathway in each WTC. The heating elements were regulated by programme-controlled relays using measured incident light intensity. When the light intensity fell below $900 \mu \mathrm{mol} \mathrm{m}{ }^{-2} \mathrm{~s}^{-1}$, one element was switched on in each $\mathrm{T}_{\mathrm{E}}$ WTC. When light intensity fell further to less than $400 \mu \mathrm{mol} \mathrm{m}{ }^{-2} \mathrm{~s}^{-1}$, the second element was switched on. This ensured that the system did not heat the WTC during daytime when incident radiation levels were sufficient to heat the WTCs.

During winter, thick polystyrene sections were placed over the floor inside each WTC to insulate the base, and additional external insulation was placed around each WTC base. This insulation simulated snow cover and prevented deep frost in the soil under the WTCs. The insulation was removed in the spring after complete snowmelt.

\section{System regulation and data acquisition}

The programme for controlling the WTC system was developed using 32-bit programming software (Visual Basic 5.0, Microsoft Corp., Redmond, WA, USA). The program was run continuously from a Pentium computer with a Windows NT 4.0 (Microsoft Corp.) operating system. The control of the WTC environment and data acquisition was achieved with an input/output (I/O) module (SIOX S12, Telefrang AB, Göteborg, Sweden). To allow multiple tasks and data acquisition this central module had a combination of analogue and digital input and outputs. Communication between the program and the I/O module was via a K30 RS232C-SIOX converter (Telefrang AB) connected to a RS232 port on the computer. The central I/O module was used to transmit and receive data from the local I/O module (SIOX S12, Telefrang AB) in each WTC, control the signal to the central cooling system, and measure reference climatic variables. Communication between the central and local I/O modules was initiated by the programme every $90 \mathrm{~s}$. The climatic data and WTC data stored by the WTC system are listed in Table 1. Climatic data was stored every 3 min. Data for each WTC was stored on a 42 min cycle after completion of the WTC gas analysis by the central infrared gas analyser (see further discussion).

A differential $\mathrm{CO}_{2} / \mathrm{H}_{2} \mathrm{O}$ infrared gas analyser (CIRAS-2 DC, PP Systems), located in a nearby temperature- controlled shelter, measured the concentrations of $\mathrm{CO}_{2}$ and $\mathrm{H}_{2} \mathrm{O}$ in air pumped from the WTCs and the reference mast. Sample gas was drawn continuously from each of the WTCs and the mast using a vacuum pump and a $6 \mathrm{~mm}$ highdensity polyethylene tubing at a rate of approximately 1.5 $\mathrm{L} \mathrm{min}^{-1}$ and directed to the analyser in turn using set of 3-way magnetic valves (M-331-c-04, Bürket). The gas samples from each WTC was analysed for $180 \mathrm{~s}$. For each measurement cycle, the analyser first measured samples from the six $\mathrm{C}_{\mathrm{A}}$ WTCs followed by a reference air sample, then the six $C_{E}$ WTCs followed by another reference air sample. The time taken to complete one measurement cycle was approximately $42 \mathrm{~min}$. During each reference gas sample, the analyser was programmed to undergo its autocalibration sequence where dry, $\mathrm{CO}_{2}$-free air was directed through the cells. To continuously update the dew point temperature target for the central cooling system, the continuous measurement of water vapour pressure of the reference air was used. The digital data from the analyser was transmitted to the computer via a RS232 port. A 56K data modem and remote access software (pcANYWHERE 7.5, Symantec Corp., Cupertino, CA, USA) enabled remote control of the computer and the WTC system.

\section{WTC performance test}

\section{Sample data}

Two sets of data were used to assess the effectiveness of the system in controlling the air temperature, water vapour pressure and maintaining the target $\left[\mathrm{CO}_{2}\right]$, within the WTCs. All WTCs were used in the evaluation of chamber performance. The first dataset was a $14 \mathrm{~d}$ period during the winter (14-28 February 2002). The second dataset was a $14 \mathrm{~d}$ period during late spring 2002 (3-17 May) that was characterized by unseasonally high air temperatures (Fig. 3). These time periods were relatively free of disruptions caused by personnel entering the WTCs for routine tree measurements, equipment maintenance or repairs.

\section{Temperature and water vapour pressure control}

The air temperatures inside and outside of each WTC, measured at 42 min intervals, were compared throughout each of the winter and spring $14 \mathrm{~d}$ periods, which were used to illustrate the performance of the temperature control of the WTCs. Mean temperature differences were calculated for $\mathrm{T}_{\mathrm{A}}$ and $\mathrm{T}_{\mathrm{E}}$ treatments. In February, the target temperature for the $\mathrm{T}_{\mathrm{E}} \mathrm{WTCs}$ was $+4.7^{\circ} \mathrm{C}$ and in May the target was $+3.1^{\circ} \mathrm{C}$ above ambient temperature, respectively.

The water vapour pressure deficit (VPD) of the WTC and reference air was compared for each WTC using instantaneous measurements of air vapour pressure and temperature. Measurements were made on a 42 min cycle.

\section{$\left[\mathrm{CO}_{2}\right]$ control}

The $\left[\mathrm{CO}_{2}\right]$ inside and outside of each WTC, measured at 42 min intervals, was compared throughout each of the 
Table 1. Climatic data and whole-tree chamber (WTC) data automatically stored by the WTC system every 3 and 42 min, respectively

\begin{tabular}{|c|c|c|c|}
\hline Variable name & Units & Symbol $^{\mathrm{a}}$ & Notes \\
\hline \multicolumn{4}{|l|}{ Dataset 1 - climatic data (3 min cycle) } \\
\hline Reference air temperature & ${ }^{\circ} \mathrm{C}$ & & \\
\hline Photosynthetic photon flux density (PPFD) & $\mu \mathrm{mol} \mathrm{m}{ }^{-2} \mathrm{~s}^{-1}$ & & Integrated value using a 12 min time interval \\
\hline Barometric air pressure & $\mathrm{Pa}$ & & \\
\hline Reference air $\mathrm{CO}_{2}$ concentration & $\mu \mathrm{mol} \mathrm{mol}^{-1}$ & & From reference cell of central IRGA \\
\hline Reference air vapour pressure & $\mathrm{kPa}$ & & From reference cell of central IRGA \\
\hline Reference air vapour pressure deficit & $\mathrm{kPa}$ & & Calculated from temperature and water vapour pressure \\
\hline \multicolumn{4}{|c|}{ Dataset 2 - Current WTC data (recorded for each WTC on a 42 min cycle) } \\
\hline WTC air $\mathrm{CO}_{2}$ concentration & $\mu \mathrm{mol} \mathrm{mol}{ }^{-1}$ & $c_{\mathrm{t}} \& c_{\mathrm{t}-1}$ & From central IRGA \\
\hline Reference air $\mathrm{CO}_{2}$ concentration & $\mu \mathrm{mol} \mathrm{mol}{ }^{-1}$ & & From central IRGA \\
\hline WTC air vapour pressure & $\mathrm{kPa}$ & $H_{\mathrm{WTC}}$ & From central IRGA \\
\hline Reference air vapour pressure & $\mathrm{kPa}$ & & From central IRGA \\
\hline WTC air temperature & ${ }^{\circ} \mathrm{C}$ & & \\
\hline Reference air temperature & ${ }^{\circ} \mathrm{C}$ & & \\
\hline PPFD & $\mu \mathrm{mol} \mathrm{m}{ }^{-2} \mathrm{~s}^{-1}$ & & Integrated value using a 12 min time interval \\
\hline Barometric air pressure & $\mathrm{Pa}$ & & \\
\hline WTC air $\mathrm{CO}_{2}$ concentration & $\mu \mathrm{mol} \mathrm{mol}^{-1}$ & & From WTC $\mathrm{CO}_{2}$ infra-red gas analyser \\
\hline $\mathrm{CO}_{2}$ addition flow rate & $\mathrm{mL} \mathrm{s}^{-1}$ & & Averaged by WTC I/O module per second of flow \\
\hline $\mathrm{CO}_{2}$ addition time & s & & Total opening time of magnetic valve during cycle \\
\hline Differential pressure across fresh air iris & $\mathrm{Pa}$ & & \\
\hline Condensed water & $\mathrm{g}$ & & Amount of water condensed from WTC during cycle \\
\hline Dendrometer & $\Delta \mathrm{mm}$ & & Circumferential stem growth at $1.3 \mathrm{~m}$ height \\
\hline Soil volumetric water content & $\mathrm{m}^{3} \mathrm{~m}^{-3}$ & & \\
\hline Soil temperature & ${ }^{\circ} \mathrm{C}$ & & At $10 \mathrm{~cm}$ depth \\
\hline Floor air temperature & ${ }^{\circ} \mathrm{C}$ & & Air temperature under floor of WTC \\
\hline Door alarm counter & & & Number of WTC door openings during cycle \\
\hline \multicolumn{4}{|c|}{ Dataset 3 - Mean WTC data (recorded on 42 min cycle; mean values calculated from 90 s readings) } \\
\hline Mean reference air $\mathrm{CO}_{2}$ concentration & $\mu \mathrm{mol} \mathrm{mol}{ }^{-1}$ & $C_{\text {ref }}$ & From central IRGA \\
\hline Mean WTC air $\mathrm{CO}_{2}$ concentration & $\mu \mathrm{mol} \mathrm{mol}^{-1}$ & $C_{\mathrm{WTC}}$ & From central IRGA \\
\hline Mean PPFD & $\mu \mathrm{mol} \mathrm{m}{ }^{-2} \mathrm{~s}^{-1}$ & & \\
\hline Mean WTC air temperature & ${ }^{\circ} \mathrm{C}$ & $T_{\mathrm{WTC}}$ & \\
\hline Mean reference air temperature & ${ }^{\circ} \mathrm{C}$ & $T_{\text {ref }}$ & \\
\hline $\begin{array}{l}\text { Mean } \mathrm{CO}_{2} \text { addition flow rate when } \mathrm{CO}_{2} \text { valve } \\
\text { was open }\end{array}$ & $\mathrm{mL} \mathrm{s}^{-1}$ & $f$ & \\
\hline Total $\mathrm{CO}_{2}$ injection time & $\mathrm{s}$ & $t_{\mathrm{CO} 2}$ & \\
\hline Total cycle time & $\mathrm{s}$ & $t_{\mathrm{tot}}$ & Time of measurement cycle \\
\hline Mean barometric air pressure & $\mathrm{Pa}$ & $P_{\text {atm }}$ & \\
\hline Mean differential pressure across fresh air iris & $\mathrm{Pa}$ & $\Delta \mathrm{P}$ & \\
\hline Mean reference air vapour pressure & $\mathrm{kPa}$ & $H_{\text {ref }}$ & From central IRGA \\
\hline
\end{tabular}

Data acquisition and storage was achieved with the central I/O module (see text for details).

${ }^{a}$ Symbols as used in Eqns 3-10. For further explanations, see text.

winter and spring $14 \mathrm{~d}$ periods, and mean concentration differences were calculated for the $\mathrm{C}_{\mathrm{A}}$ and $\mathrm{C}_{\mathrm{E}}$ treatments.

\section{Radiation quality and quantity}

Light transmission through the WTC wall material was measured using a portable spectroradiometer Li-1800 (Li-Cor Inc.). The spectrum runs ranged from 300 to $1100 \mathrm{~nm}$, with a measurement recorded for each $\mathrm{nm}$. The spectrum was measured in direct and diffuse solar radiation during a cloud-free day. Measurements were made on WTC wall material that had been exposed to the elements for 5 years and material that had not been exposed.A total of four scans were done, the first and last being reference measurements and for the two middle scans the spectroradiometer hemispheric dome was covered with old and new WTC wall material, respectively. The four measurements were done in one 5 min sequence. The effect of the WTC structure on PPFD levels inside the WTC was examined by comparing PPFD measurements made at the fifth whorl (from the top) of the $\mathrm{R}$ trees $(n=3)$ and the $\mathrm{C}_{\mathrm{A}}$ trees $(n=6)$. The PPFD measurements were made as part of a shoot-level gas exchange system (see Wallin et al. 2001). Mean daily PPFD for each tree was calculated using measurements made every $30 \mathrm{~min}$. A 6 month period that covered a wide range of sun angles (1 January-30 June 2002) was used for the analysis.

\section{Tree-level net $\mathrm{CO}_{2}$ flux calculations}

Net $\mathrm{CO}_{2}$ uptake and release by the trees within the WTCs was calculated using the continuous measurements made 




Figure 3. Flakaliden climate [air temperature, photosynthetic photon flux density (PPFD) and water vapour pressure deficit (VPD)] for $14 \mathrm{~d}$ in February and $14 \mathrm{~d}$ in May 2002. The data shown are measurements made at 3 min intervals. Air temperature was measured at a height of $2.5 \mathrm{~m}$ and PPFD was measured at $11 \mathrm{~m}$. by the WTC system (see Table 1). Fluxes were calculated using a carbon balance approach with influx terms on the left side of the equation, and efflux terms on the right:

$I+F=V+P+S$,

where $I$ is the $\mathrm{CO}_{2}$ injection rate, $F$ is the rate of $\mathrm{CO}_{2}$ addition to the chamber in the fresh air supply, $V$ is the venting of $\mathrm{CO}_{2}$ from the chamber, $P$ is net photosynthesis, and $S$ is the change in $\mathrm{CO}_{2}$ storage in the chamber resulting from changes in $\left[\mathrm{CO}_{2}\right]$ in the WTCs over time. Solving for $P$ gives

$P=I+F-V-\Delta S$.

Each of these terms is now considered separately.

\section{(a) $\mathrm{CO}_{2}$ injection rate (I)}

The amount of $\mathrm{CO}_{2}$ injected into the chamber during a measurement cycle (approximately $42 \mathrm{~min}$ ) was calculated from the total time that the magnetic valve to the $\mathrm{CO}_{2}$ supply line was open, and the mean flow rate of $\mathrm{CO}_{2}$ through the mass flow meter. Each $\mathrm{CO}_{2}$ mass flow meter was calibrated to standard temperature and pressure $\left(0^{\circ} \mathrm{C}\right.$ and $101.3 \mathrm{kPa}$, respectively). Thus, the $\mathrm{CO}_{2}$ injection rate $\left(\mathrm{mmol} \mathrm{CO} \mathrm{CO}^{-1}\right)$ throughout each measurement cycle was calculated as

$I=\frac{\left(\frac{f}{22.4}\right) t_{\mathrm{CO}_{2}}}{t_{\mathrm{tot}}}$

where $f$ was the mean $\mathrm{CO}_{2}$ flow rate when $\mathrm{CO}_{2}$ valve was open $\left(\mathrm{mL} \mathrm{s}^{-1}\right), t_{\mathrm{CO}_{2}}$ the total time the $\mathrm{CO}_{2}$ valve was open during the measurement cycle (s), and $t_{\text {tot }}$ the total time of the measurement cycle (s).

\section{(b) $\mathrm{CO}_{2}$ addition via fresh air supply $(F)$}

The amount of $\mathrm{CO}_{2}$ added to the chamber via the fresh air supply was calculated from the volume of fresh air entering the chamber and its $\left[\mathrm{CO}_{2}\right]$. Before the volumetric flow rate of fresh air could be determined, the density of the fresh air $\left(D_{\text {ref }}, \mathrm{g}^{-1}\right)$ was calculated as

$$
D_{\text {ref }}=\frac{P_{\text {atm }} / R T_{\text {ref }}}{\left(1-H_{\text {ref }} / P_{\text {atm }}\right) *(1-0.622)}
$$

where $P_{\text {atm }}$ was mean atmospheric pressure throughout the measurement cycle $(\mathrm{Pa}), R$ the gas constant $\left(287 \mathrm{~J} \mathrm{~K}^{-1} \mathrm{~kg}^{-1}\right)$, 
$T_{\text {ref }}$ the mean temperature of the reference air during the measurement period (Kelvin, $\mathrm{K}$ ) and $H_{\text {ref }}$ the vapour pressure of the reference air during the measurement $(\mathrm{Pa})$. The volumetric flow of fresh air entering the chamber $\left(A_{\text {in }}, 1 \mathrm{~s}^{-1}\right)$, corrected to standard temperature and pressure, was then calculated as

$$
A_{\text {in }}=\left(k \sqrt{\Delta P \frac{1.2}{D_{\text {ref }}}}\right) \frac{273}{T_{\text {ref }}} \frac{P_{\text {atm }}}{1013}
$$

where $k$ was a chamber-specific constant calculated from calibrating the air flow at a set iris position using an inflatable bag of known volume, and $\Delta P$ was the mean pressure differential $(\mathrm{Pa})$ across the iris of the fresh air inlet during the measurement cycle. The rate of addition of $\mathrm{CO}_{2}$ by the fresh air supply $\left(\mathrm{mmol} \mathrm{s}^{-1}\right)$ during the measurement cycle was then calculated as

$$
F=\frac{A_{\text {in }} C_{\text {ref }}}{22400}
$$

where $C_{\text {ref }}$ was the mean $\left[\mathrm{CO}_{2}\right]\left(\mu \mathrm{L} \mathrm{l}^{-1}\right)$ of reference air throughout the measurement cycle. The mean $\left[\mathrm{CO}_{2}\right]$ of the reference air was calculated from the CIRAS-DC IRGA measurements made every $3 \mathrm{~min}$.

\section{(c) $\mathrm{CO}_{2}$ venting from the chamber $(\mathrm{V})$}

The loss of $\mathrm{CO}_{2}$ from the chamber by venting was calculated using the same method as (b) and replacing mean reference air variables with mean chamber air variables. The mean air density of the chamber during the measurement cycle $\left(D_{\text {WTC }}, \mathrm{g}^{-1}\right)$ was calculated as

$$
D_{\mathrm{WTC}}=\frac{P_{\mathrm{atm}} / R T_{\mathrm{WTC}}}{\left(1-H_{\mathrm{WTC}} / P_{\mathrm{atm}}\right) *(1-0.622)}
$$

where $T_{\text {wTC }}$ was the mean air temperature $(\mathrm{K})$ in the chamber during the measurement cycle and $H_{\text {WTC }}$ was the vapour pressure $(\mathrm{Pa})$ of the chamber air.

The air flow out of the chamber $\left(A_{\text {out }}, 1 \mathrm{~s}^{-1}\right)$ was then calculated as

$$
A_{\text {out }}=\left(k \sqrt{\Delta P \frac{1.2}{D_{\mathrm{wTC}}}}\right) \frac{273}{T_{\mathrm{WTC}}} \frac{P_{\mathrm{atm}}}{1013}
$$

where $T_{\text {WTC }}$ was the mean chamber temperature $(\mathrm{K})$ during the measurement cycle. The rate of $\mathrm{CO}_{2}$ loss from the chamber by venting $\left(V, \mathrm{mmol} \mathrm{s}^{-1}\right)$ during the measurement cycle was then calculated as

$V=\frac{A_{\text {out }} C_{\mathrm{wTC}}}{22400}$

where $C_{\text {WTC }}$ was the mean $\left[\mathrm{CO}_{2}\right]\left(\mu \mathrm{L} \mathrm{l}^{-1}\right)$ of the chamber air throughout the measurement cycle.

\section{(d) Change in $\mathrm{CO}_{2}$ storage in the chamber $(\mathrm{S})$}

To calculate the rate of change in storage of $\mathrm{CO}_{2}$ in the chamber during the measurement cycle $\left(\mathrm{mmol} \mathrm{s}^{-1}\right)$, the chamber $\left[\mathrm{CO}_{2}\right]$ measured by the CIRAS-DC gas analyser, $c_{\mathrm{t}}\left(\mu \mathrm{L} \mathrm{l}^{-1}\right)$ was compared with that measured during the previous measurement cycle, $c_{\mathrm{t}-1}\left(\mu \mathrm{L} \mathrm{l}^{-1}\right)$.

$S=\frac{\left(c_{\mathrm{t}}-c_{\mathrm{t}-1}\right) v}{22.4} * \frac{1}{T}$

where $v$ was chamber volume $\left(\mathrm{m}^{3}\right)$. The $S$-value was a small part of the carbon balance equation because of the stable $\left[\mathrm{CO}_{2}\right]$ maintained in the chamber by the control system (see Results). Typically the $S$-value was less than $2 \%$ of the $\mathrm{CO}_{2}$ injection term.

\section{WTC effects and tree-level net $\mathrm{CO}_{2}$ flux in response to climate}

The effect of the WTCs on the functioning of the enclosed trees was examined by comparing a range of structural characteristics and physiological parameters from the trees grown inside ambient temperature and $\left[\mathrm{CO}_{2}\right]$ WTCs $\left(\mathrm{T}_{\mathrm{A}} \mathrm{C}_{\mathrm{A}}\right)$ and non-chambered trees $(\mathrm{R})$. The analysis of the structural characteristics of the wood and needles included both the (1) material that was formed prior to the installation of the WTC (i.e. 2001) and (2) material that was formed during the last year of the experiment (2004). The majority of the physiological data used for the analysis was collected in the spring of 2002. Unpaired Student's $t$-tests were used to test the statistical significance of differences between $\mathrm{R}$ and $\mathrm{T}_{\mathrm{A}} \mathrm{C}_{\mathrm{A}}$ values.

To illustrate the ability of the WTC system to examine tree-level responses to environmental variation, the net $\mathrm{CO}_{2}$ uptake and release was calculated for one $\mathrm{T}_{\mathrm{A}} \mathrm{C}_{\mathrm{A}}$ WTC and one $\mathrm{T}_{\mathrm{E}} \mathrm{C}_{\mathrm{A}}$ WTC from January to December 2003 using Eqns 3-10.

The response of tree-level net $\mathrm{CO}_{2}$ uptake to air temperature, air water VPD and PPFD was examined by using the 2003 data from the $T_{E} C_{A}$ chamber. Daily mean and daily maximum WTC data were used for this exercise. The response of tree-level maximum respiration rate to a $10{ }^{\circ} \mathrm{C}$ increase in temperature, $Q_{10}$, was calculated for the $\mathrm{T}_{\mathrm{E}} \mathrm{C}_{\mathrm{A}}$ tree by plotting the natural logarithm of mean respiration rate as a function of mean air temperature using data when PPFD was less than $25 \mu \mathrm{mol} \mathrm{m}{ }^{-2} \mathrm{~s}^{-1}$ :

$Q_{10}=\exp (10 \beta)$

where $\beta$ is the slope. The fitted regression was also used to calculate $R_{0}$ and $R_{15}$, the maximum respiration rate at 0 and $15^{\circ} \mathrm{C}$, respectively.

\section{RESULTS}

\section{$\left[\mathrm{CO}_{2}\right]$ control}

Excellent $\left[\mathrm{CO}_{2}\right]$ control was achieved in the $\mathrm{C}_{\mathrm{E}}$ WTCs during both measurement periods (Table 2). The $\left[\mathrm{CO}_{2}\right]$ of the $\mathrm{C}_{\mathrm{E}}$ WTCs was between 690 and $710 \mu \mathrm{mol} \mathrm{mol}^{-1}$ for 98 and $93 \%$ of the time for the winter and spring periods, respectively (Fig. 4). The target $\left[\mathrm{CO}_{2}\right]$ of $365 \mu \mathrm{mol} \mathrm{mol}^{-1}$ in the $\mathrm{C}_{\mathrm{A}}$ WTCs was, however, not achieved during the winter period: 
Table 2. Regulation of $\left[\mathrm{CO}_{2}\right]$ in the whole-tree chambers (WTC) by $\left[\mathrm{CO}_{2}\right]$ treatment

\begin{tabular}{|c|c|c|c|c|c|}
\hline $\begin{array}{l}\mathrm{CO}_{2} \\
\text { treatment }\end{array}$ & $\begin{array}{l}\text { Target }\left[\mathrm{CO}_{2}\right] \\
\left(\mu \mathrm{mol} \mathrm{mol}^{-1}\right)\end{array}$ & $\begin{array}{l}\text { Mean difference from } \\
\text { target }\left(\mu \mathrm{mol} \mathrm{mol}^{-1}\right)\end{array}$ & $\begin{array}{l}\text { Standard } \\
\text { Deviation }\end{array}$ & $\begin{array}{l}\text { 10th percentile } \\
\left(\mu \mathrm{mol} \mathrm{mol}^{-1}\right)\end{array}$ & $\begin{array}{l}\text { 90th percentile } \\
\left(\mu \mathrm{mol} \mathrm{mol}^{-1}\right)\end{array}$ \\
\hline \multicolumn{6}{|c|}{ 14-28 February 2002} \\
\hline $\mathrm{C}_{\mathrm{A}}$ & 365 & +20.1 & \pm 5.0 & +15.3 & +23.5 \\
\hline $\mathrm{C}_{\mathrm{E}}$ & 700 & +2.4 & \pm 3.3 & -0.8 & +5.3 \\
\hline \multicolumn{6}{|c|}{ 3-17 May 2002} \\
\hline $\mathrm{C}_{\mathrm{A}}$ & 365 & +8.9 & \pm 14.9 & -6.5 & +25.0 \\
\hline $\mathrm{C}_{\mathrm{E}}$ & 700 & -1.6 & \pm 5.8 & -7.4 & +3.5 \\
\hline
\end{tabular}

The $\left[\mathrm{CO}_{2}\right]$ values measured by the central IRGA on a 42 min cycle from each WTC were pooled by $\left[\mathrm{CO}_{2}\right]$ treatment. $n=6$.

$\mathrm{C}_{\mathrm{A}}$, ambient $\left[\mathrm{CO}_{2}\right] ; \mathrm{C}_{\mathrm{E}}$, elevated $\left[\mathrm{CO}_{2}\right]$.

The $\left[\mathrm{CO}_{2}\right]$ in the $\mathrm{C}_{\mathrm{A}}$ WCTs was between 355 and $375 \mu \mathrm{mol} \mathrm{mol}^{-1}$ for only $5 \%$ of the time. This was because of tree dormancy and the naturally high $\left[\mathrm{CO}_{2}\right]$ of the fresh ambient air entering the WTCs during this period. During the spring period, the $\left[\mathrm{CO}_{2}\right]$ of the $\mathrm{C}_{\mathrm{A}}$ WTCs was between 355 and $375 \mu \mathrm{mol} \mathrm{mol}^{-1}$ for $51 \%$ of the time.

\section{Temperature control}

Temperature regulation displayed a high level of accuracy throughout both measurement periods (Table 3). In the $\mathrm{T}_{\mathrm{E}}$
WTCs, the temperature was within $\pm 0.5^{\circ} \mathrm{C}$ of the target temperature for $99 \%$ of the time of both measurement periods (Fig. 5). The reduction in cooling capacity during the winter period meant that the temperature of the air in $\mathrm{T}_{\mathrm{A}}$ WTCs was within $\pm 0.5^{\circ} \mathrm{C}$ of ambient temperature for $54 \%$ of the time (and within $\pm 1.0{ }^{\circ} \mathrm{C}$ for $80 \%$ of the time). With full cooling capacity reinstated in the spring, the temperature of the air in $\mathrm{T}_{\mathrm{A}}$ WTCs was within $\pm 0.5^{\circ} \mathrm{C}$ of ambient temperature for $89 \%$ of the time (and within $\pm 1.0^{\circ} \mathrm{C}$ for $97 \%$ of the time).

Humidity control in the $\mathrm{T}_{\mathrm{A}}$ WTCs was of high standard
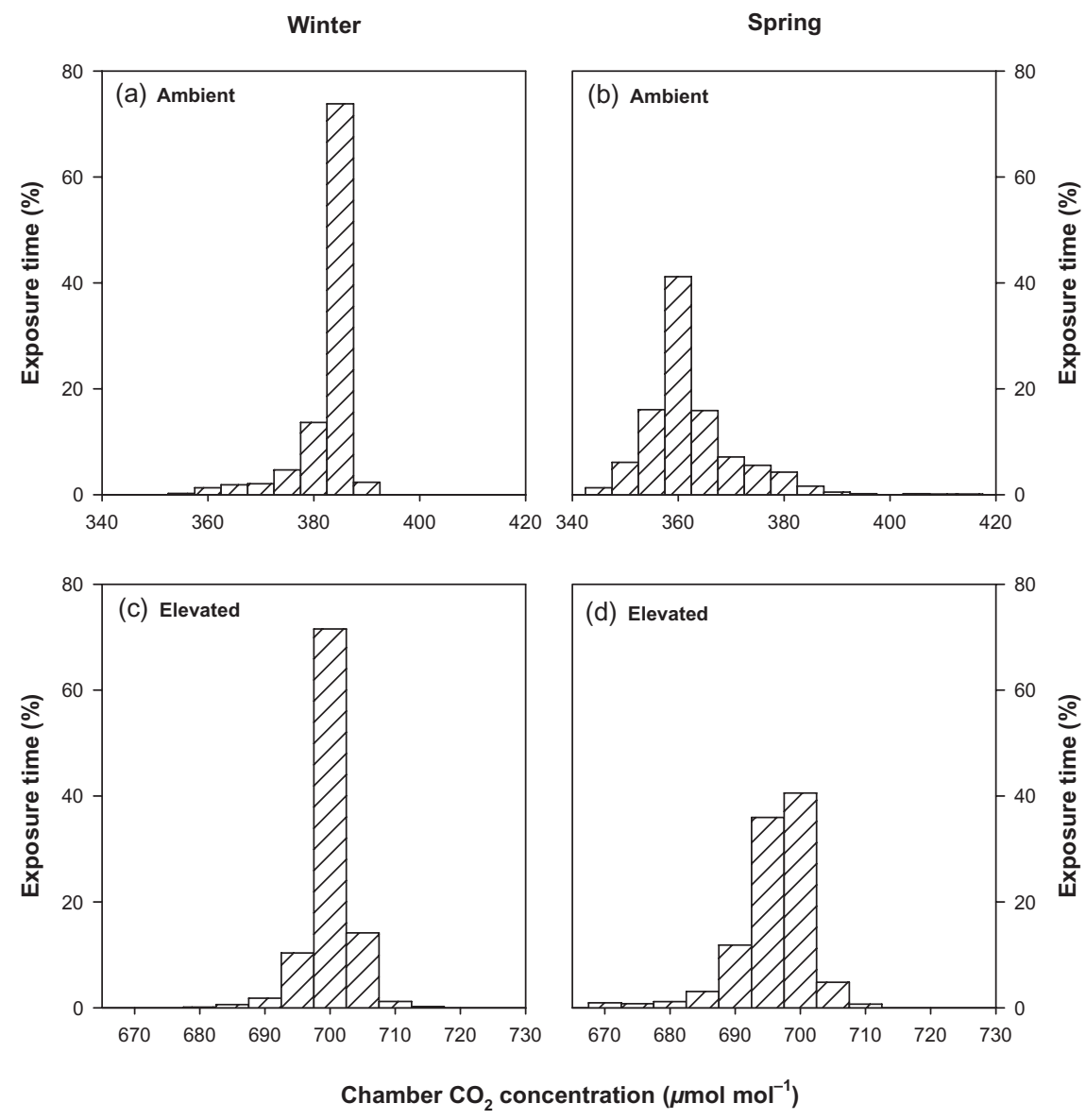

Figure 4. Frequency distributions of $\left[\mathrm{CO}_{2}\right]$ in the ambient, $\mathrm{C}_{\mathrm{A}}(\mathrm{a} \& \mathrm{~b})$, and elevated, $C_{E}(c \& d)$, chambers for the measurement periods 14-28 February and 3-17 May, 2002. Frequency distributions were calculated from the central IRGA measurements made on a 42 min cycle from the six $\mathrm{C}_{\mathrm{A}}$ and six $\mathrm{C}_{\mathrm{E}}$ whole-tree chambers, respectively. 
Table 3. Whole-tree chamber (WTC) temperature control by temperature treatment

\begin{tabular}{llllll}
\hline $\begin{array}{l}\text { Temperature } \\
\text { treatment }\end{array}$ & $\begin{array}{l}\text { Target temperature } \\
\text { elevation }\left({ }^{\circ} \mathrm{C}\right)\end{array}$ & $\begin{array}{l}\text { Mean temperature difference } \\
\text { from ambient }\left({ }^{\circ} \mathrm{C}\right)\end{array}$ & $\begin{array}{l}\text { Standard } \\
\text { Deviation }\end{array}$ & $\begin{array}{l}\text { 10th percentile } \\
\left({ }^{\circ} \mathrm{C}\right)\end{array}$ & $\begin{array}{l}\text { 90th percentile } \\
\left({ }^{\circ} \mathrm{C}\right)\end{array}$ \\
\hline $\begin{array}{l}14-28 \text { February 2002 } \\
\mathrm{T}_{\mathrm{A}}\end{array}$ & 0 & & & & \\
$\mathrm{~T}_{\mathrm{E}}$ & +4.7 & +0.6 & \pm 0.6 & 0.0 & +1.3 \\
$3-17$ May 2002 & & +4.8 & \pm 0.2 & +4.6 & +5.0 \\
$\mathrm{~T}_{\mathrm{A}}$ & 0 & 0.0 & \pm 0.4 & -0.3 & +0.3 \\
$\mathrm{~T}_{\mathrm{E}}$ & +3.1 & +3.1 & \pm 0.2 & +3.0 & +3.4 \\
\hline
\end{tabular}

Note that during February the temperature control was deliberately reduced to minimize excessive power consumption over the winter months. Temperatures measured on a 42 min cycle from each WTC were pooled by temperature treatment $(n=6)$.

$T_{A}$, ambient temperature; $T_{E}$, elevated temperature.

throughout both measurement periods (Fig. 6). In the $\mathrm{T}_{\mathrm{A}}$ WTCs, the mean VPD was $0.02 \mathrm{kPa}$ higher than the outside air for the winter measurement period $(\mathrm{SD}=0.02)$. In the spring measurement period, the mean VPD in the $\mathrm{T}_{\mathrm{A}}$ WTCs was the same as the outside air $(\mathrm{SD}=0.02 \mathrm{kPa})$. The higher temperatures in the $\mathrm{T}_{\mathrm{E}}$ WTCs meant that VPD was significantly higher in these WTCs, relative to the outside air. During the winter and spring measurement periods the maximum VPD of the outside air was 0.44 and $2.28 \mathrm{kPa}$, respectively. The mean increase in VPD for the $T_{E}$ WTCs during the same periods was 0.19 and $0.30 \mathrm{kPa}$, respectively $(\mathrm{SD}=0.06$ and 0.08$)$.

\section{Light transmittance}

The new polyethylene film used in construction of the WTC walls had a high transmittance of visible light (88\%) at wavelengths of $400-800 \mathrm{~nm}$. After 5 years of exposure, the old polyethylene film had only a small decrease $(4 \%)$ in light transmittance in the visible spectral range. This decrease was largely confined to the $400-500 \mathrm{~nm}$ range of the spectrum. The amount of light transmitted at wavelengths less than $400 \mathrm{~nm}$ decreased sharply for both the new and old film. At $350 \mathrm{~nm}$ there was only 4 and $1 \%$ light transmission for the new and old film, respectively. High
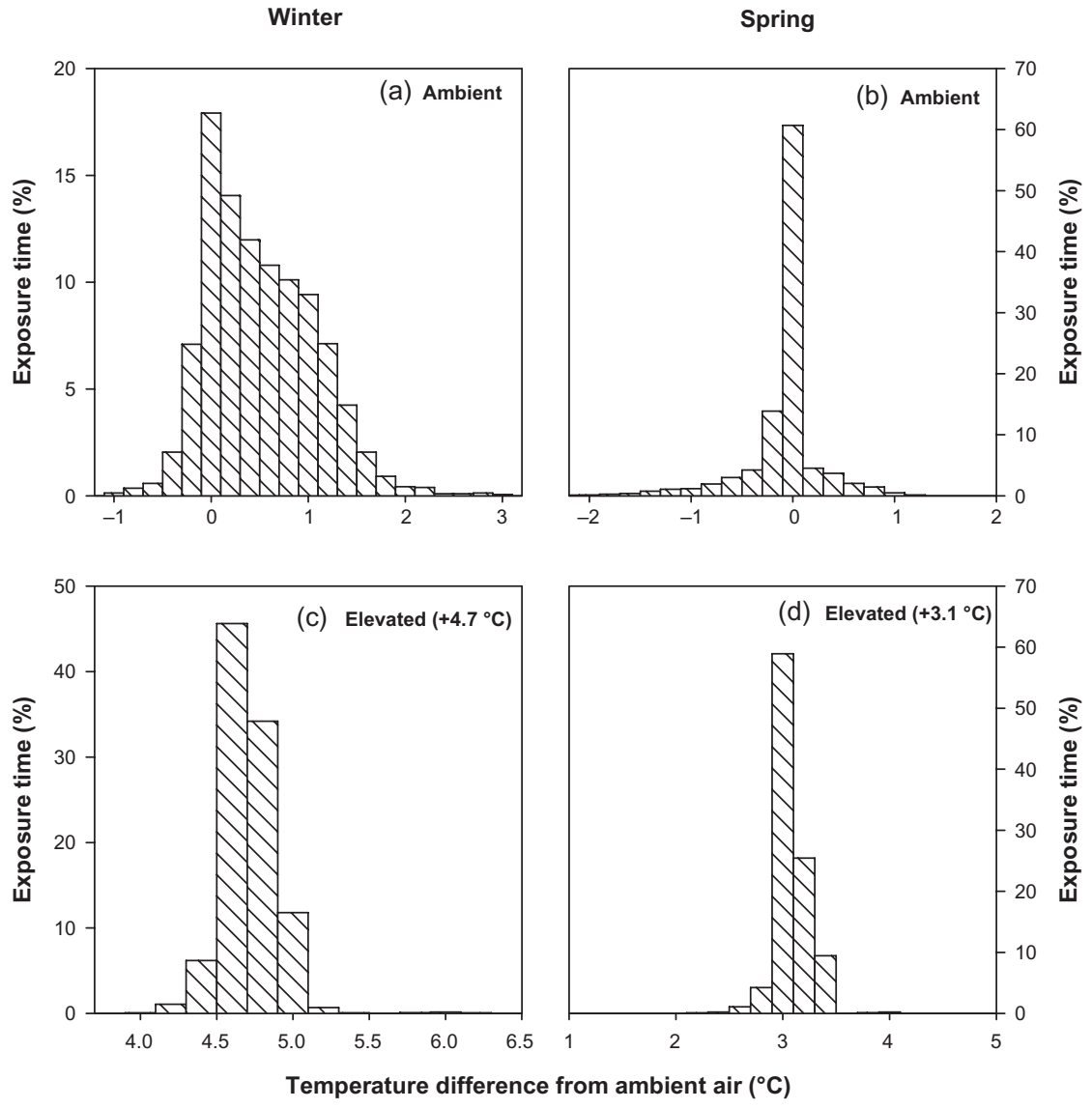

Figure 5. Frequency distributions of temperature in the ambient, $\mathrm{T}_{\mathrm{A}}(\mathrm{a} \& \mathrm{~b})$, and elevated, $\mathrm{T}_{\mathrm{E}}(\mathrm{c} \& \mathrm{~d})$, chambers for the measurement periods 14-28 February, and 3-17 May, 2002. Frequency distributions were calculated using temperature measurements from the six $T_{A}$ chambers and the six $\mathrm{T}_{\mathrm{E}}$ chambers measured at $42 \mathrm{~min}$ intervals. The target temperature elevations in February and May were $+4.7^{\circ} \mathrm{C}$ and $+3.1^{\circ} \mathrm{C}$, respectively. 


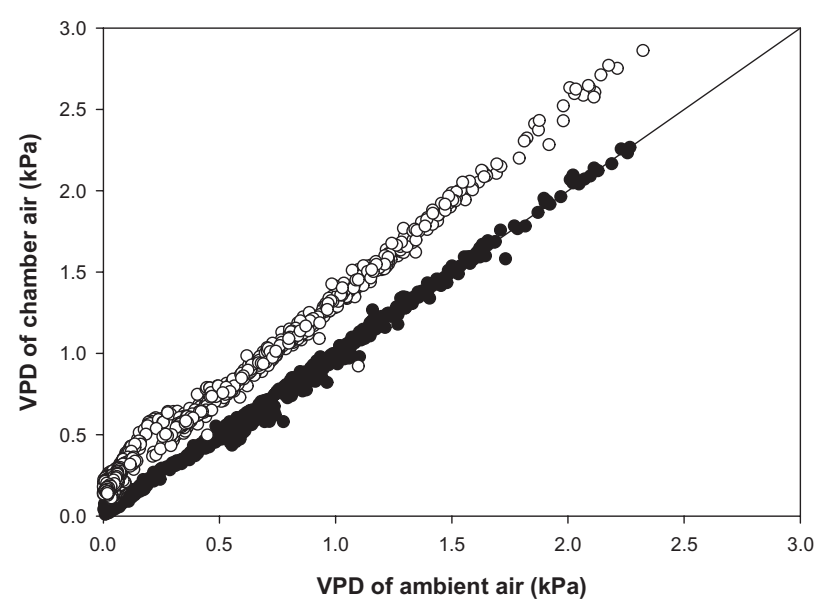

Figure 6. Water vapour pressure deficit (VPD) of an ambient temperature, $\mathrm{T}_{\mathrm{A}}$, chamber (filled symbols) and an elevated temperature, $\mathrm{T}_{\mathrm{E}}$, chamber (open symbols) by reference air VPD. Data from the time periods of 14-28 February and 3-17 May 2002 are pooled for each chamber.

transmittance levels of 88 and $89 \%$ were measured in the $800-1100 \mathrm{~nm}$ range for the old and new film, respectively.

The daily mean PPFD inside the WTCs was $21 \%$ less than that outside the WTCs for a 6 month period from 1 January to 30 June 2002 (Fig. 7).

\section{WTC effects}

An analysis of a range of structural characteristics and physiological parameters of trees in $\mathrm{T}_{\mathrm{A}} \mathrm{C}_{\mathrm{A}}$ WTCs and $\mathrm{R}$ trees showed minimal WTC effect on tree performance and function (Table 4). Wood structure and chemistry of the $\mathrm{T}_{\mathrm{A}} \mathrm{C}_{\mathrm{A}}$ trees were unaffected after 4 years of growth inside the WTCs. No significant differences were detected between the mean light-saturated photosynthetic rate,

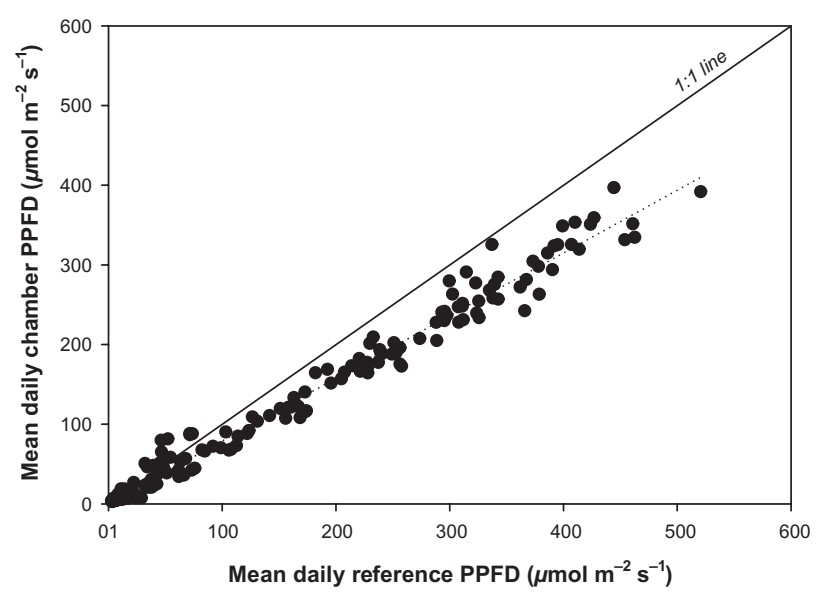

Figure 7. Relationship between the mean daily photosynthetic photon flux density (PPFD) reaching the fifth or sixth whorl from the top of reference and whole-tree chamber (ambient $\left[\mathrm{CO}_{2}\right]$ only) trees for the period of 1 January-30 June 2002. The regression line was forced through the origin $\left(y=0.79 x ; r^{2}=0.98 ; P<0.001\right)$. mean apparent quantum yield and the variable fluorescence of $T_{A} C_{A}$ and $R$ shoots during 2002. There were significant differences in phenology between $\mathrm{T}_{\mathrm{A}} \mathrm{C}_{\mathrm{A}}$ and $\mathrm{R}$ trees during spring 2002, with a lower temperature sum required for bud burst for the $\mathrm{T}_{\mathrm{A}} \mathrm{C}_{\mathrm{A}}$ trees (Table 4). There was a significant difference in the stable carbon isotope composition $\left(\delta^{13} \mathrm{C}\right)$ of the bulk needle material in the $\mathrm{T}_{\mathrm{A}} \mathrm{C}_{\mathrm{A}}$ trees when compared with the $\delta^{13} \mathrm{C}$ of the $\mathrm{R}$ trees, but not in starch (Table 4).

\section{Annual tree net $\mathrm{CO}_{2}$ flux and response curves}

There was a pronounced seasonal pattern of net $\mathrm{CO}_{2}$ exchange for both the $T_{A} C_{A}$ and $T_{E} C_{A}$ trees during 2003 (Fig. 8). The $\mathrm{T}_{\mathrm{E}} \mathrm{C}_{\mathrm{A}}$ tree showed slightly earlier spring recovery of photosynthetic activity during March-April and a later decline in photosynthetic activity during
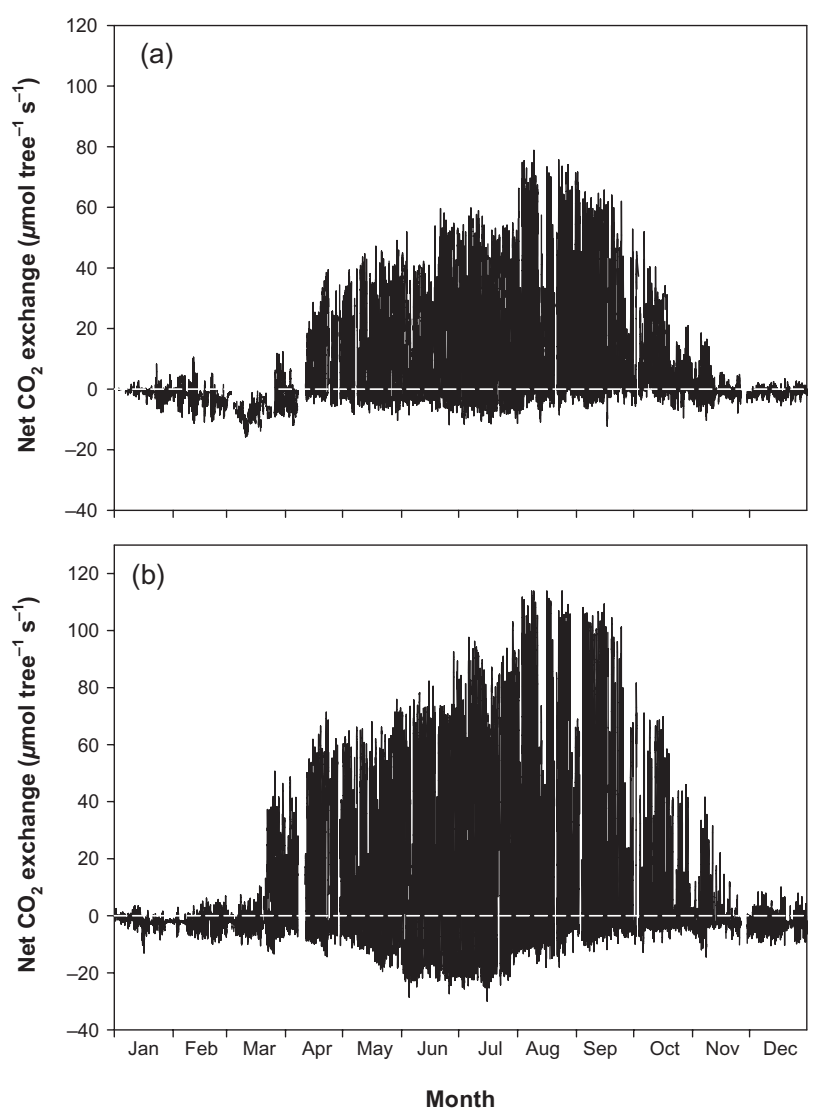

Figure 8. Annual course of net $\mathrm{CO}_{2}$ exchange of a tree exposed to ambient temperature and $\left[\mathrm{CO}_{2}\right], \mathrm{T}_{\mathrm{A}} \mathrm{C}_{\mathrm{A}}$ (a) and a tree exposed to elevated temperature and ambient $\left[\mathrm{CO}_{2}\right], \mathrm{T}_{\mathrm{E}} \mathrm{C}_{\mathrm{A}}(\mathrm{b})$, throughout 2003. Values shown are the maximum daytime rates of net $\mathrm{CO}_{2}$ uptake and night-time respiration, respectively. In July 2003 the stem diameter at breast height $(1.3 \mathrm{~m})$ was 84 and $117 \mathrm{~mm}$ for the $\mathrm{T}_{\mathrm{A}} \mathrm{C}_{\mathrm{A}}$ tree and $\mathrm{T}_{\mathrm{E}} \mathrm{C}_{\mathrm{A}}$ tree, respectively. Tree surface needle area was estimated using allometric relationships derived from an earlier destructive harvest at the Flakaliden site (B. Sigurdsson, Agricultural University of Iceland, unpublished results). The estimated needle areas were 13.0 and $23.3 \mathrm{~m}^{2}$ for the $\mathrm{T}_{\mathrm{A}} \mathrm{C}_{\mathrm{A}}$ and $\mathrm{T}_{\mathrm{E}} \mathrm{C}_{\mathrm{A}}$ trees, respectively. 


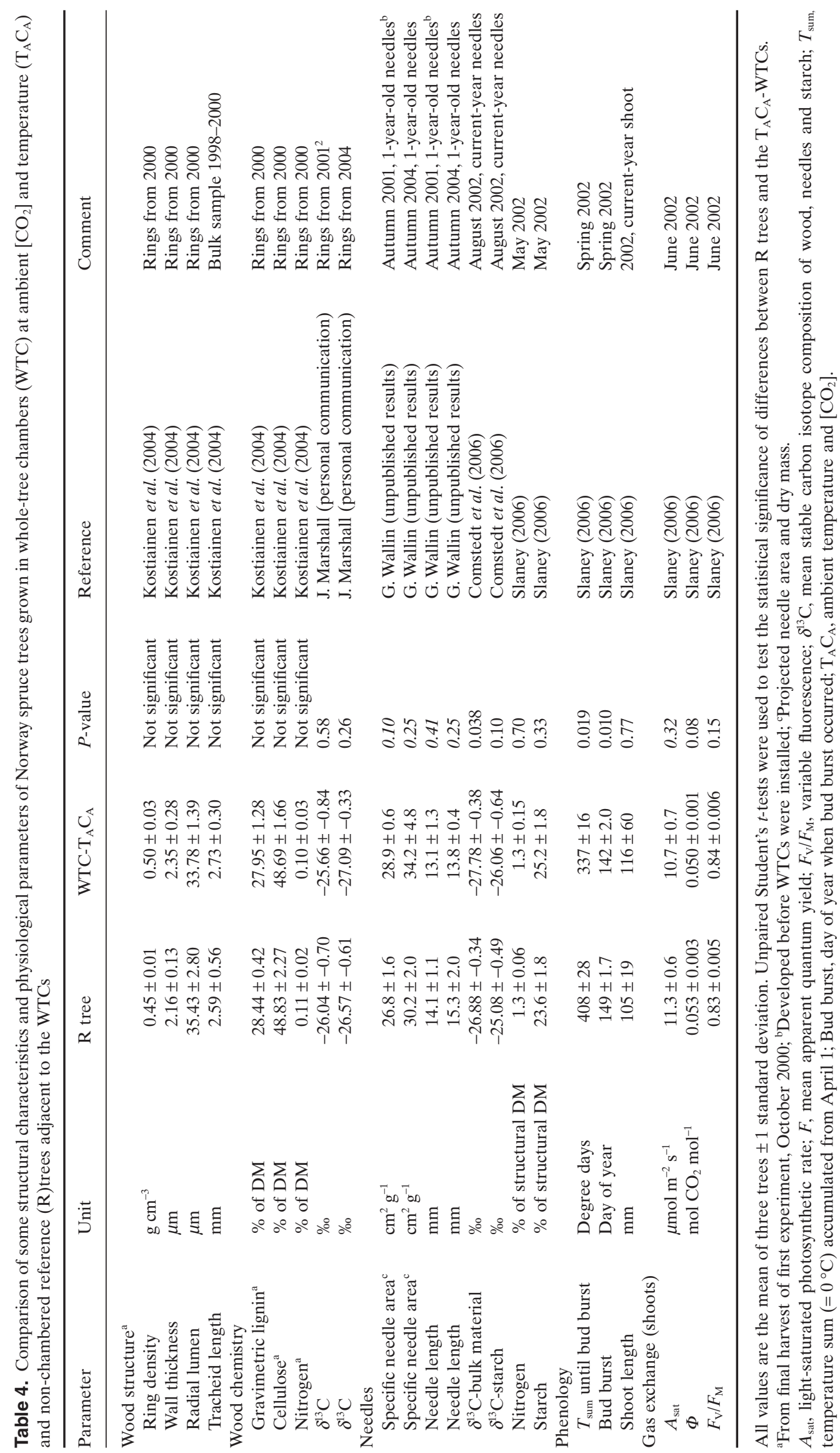



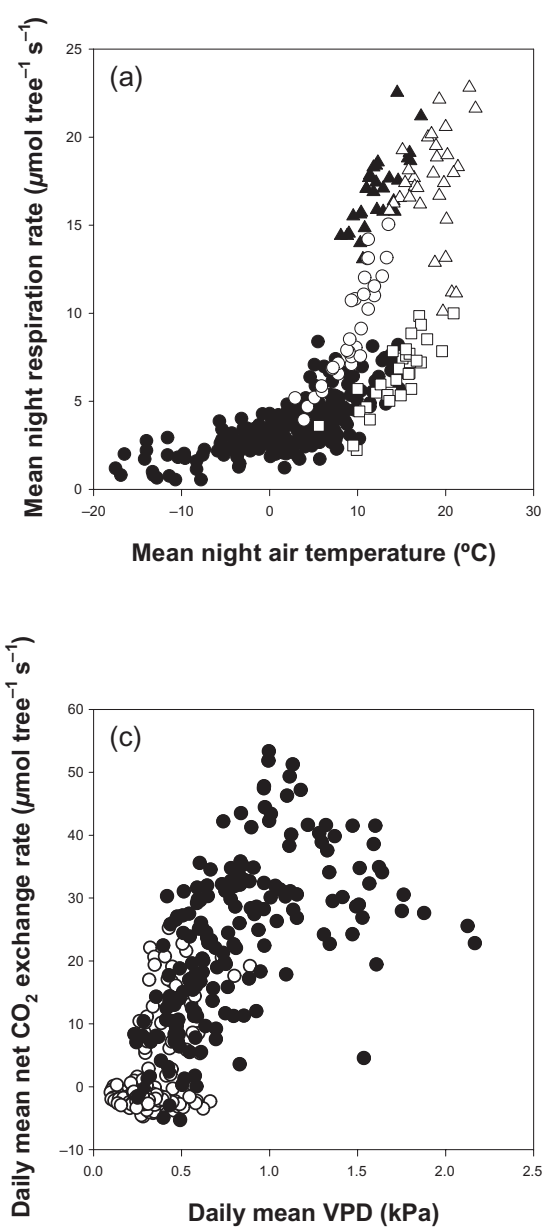
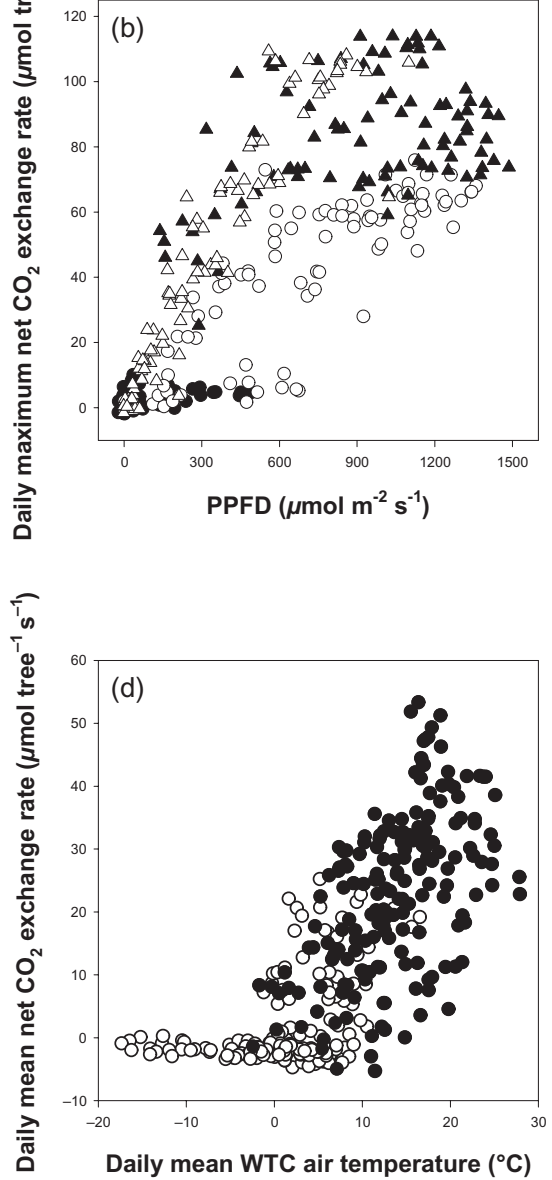

Figure 9. Four examples of tree-level response curves generated from one whole-tree chamber (WTC) with elevated-temperature and ambient $\left[\mathrm{CO}_{2}\right]$, $\mathrm{T}_{\mathrm{E}} \mathrm{C}_{\mathrm{A}}$, throughout $2003(n=362)$. (a) Mean night-time respiration rate (i.e. net $\mathrm{CO}_{2}$ exchange when photosynthetic photon flux density (PPFD) $<25 \mu \mathrm{mol}$ $\mathrm{m}^{-2} \mathrm{~s}^{-1}$ ) as a function of mean night-time air temperature inside the WTC $(O=$ May, $\boldsymbol{\Delta}$ = June, $\triangle$ = July, $\square=$ August, - = remainder of the year); (b) Maximum daily net $\mathrm{CO}_{2}$ uptake rate as a function of PPFD $(\boldsymbol{-}=$ winter, $\bigcirc=$ spring, $\boldsymbol{\Delta}=$ summer, $\triangle=$ autumn); (c) Mean daily net $\mathrm{CO}_{2}$ uptake rate as a function of mean daily air vapour pressure deficit (VPD) inside the WTC ( $=$ May-October, $\mu=$ remainder of the year); (d) mean daily air temperature inside the WTC $(-$ May-October, $\bigcirc=$ remainder of the year). Tree surface needle area was estimated to be $23.3 \mathrm{~m}^{2}$ (B. Sigurdsson, Agricultural University of Iceland, unpublished results).
October-November, when compared with the $\mathrm{T}_{\mathrm{A}} \mathrm{C}_{\mathrm{A}}$ tree. The maximum tree net $\mathrm{CO}_{2}$ uptake rate was higher for the $\mathrm{T}_{\mathrm{A}} \mathrm{C}_{\mathrm{A}}$ tree (6.1 and $4.9 \mu \mathrm{mol} \mathrm{m}^{-2} \mathrm{~s}^{-1}$ for $\mathrm{T}_{\mathrm{A}} \mathrm{C}_{\mathrm{A}}$ and $\mathrm{T}_{\mathrm{E}} \mathrm{C}_{\mathrm{A}}$, respectively) and the maximum uptake rates were measured during August night-time respiration rates were generally higher for the $\mathrm{T}_{\mathrm{E}} \mathrm{C}_{\mathrm{A}}$ tree during the summer months of June and July 2003, as compared with the $\mathrm{T}_{\mathrm{A}} \mathrm{C}_{\mathrm{A}}$ tree. The maximum respiration rate of the $\mathrm{T}_{\mathrm{A}} \mathrm{C}_{\mathrm{A}}$ and $\mathrm{T}_{\mathrm{E}} \mathrm{C}_{\mathrm{A}}$ trees during this period was 1.2 and $1.3 \mu \mathrm{mol} \mathrm{m}^{2} \mathrm{~s}^{-1}$, respectively. The cumulative respiration for the entire year was 17 and $19 \%$ of the cumulative photosynthesis for the $T_{A} C_{A}$ and $T_{E} C_{A}$ tree, respectively.

The responses of tree-level $\mathrm{CO}_{2}$ flux to climatic variation throughout 2003 are shown in Fig. $9 \mathrm{a}-\mathrm{d}\left(\mathrm{T}_{\mathrm{E}} \mathrm{C}_{\mathrm{A}}\right.$ tree only). The mean night-time respiration rates increased exponentially with mean night-time air temperature, but there was an obvious seasonal shift in the dependence of respiration on temperature throughout the growing season from May to August (Fig. 9a). The calculated annual $Q_{10}$ and $R_{0}$ values for the $\mathrm{T}_{\mathrm{E}} \mathrm{C}_{\mathrm{A}}$ tree were 2.2 and $3.1 \mu \mathrm{mol}$ tree $\mathrm{e}^{-1} \mathrm{~s}^{-1}$, respectively. Calculating $Q_{10}$ using data from each month gave a range from 1.5 to 3.3 for months where $r^{2}>0.5$. Calculating $R_{0}$ on a monthly time-step throughout the growing season (May-August) showed that respiration varied substantially throughout this period with $R_{0}$ values of 2.9, 10.5 and $1.6 \mu \mathrm{mol} \mathrm{tree}^{-1} \mathrm{~s}^{-1}$ for May, June and August, respectively. There was similar magnitude in the seasonal variation of $R_{15}$ with values ranging between 6.5 and $18.7 \mu \mathrm{mol} \mathrm{tree}^{-1} \mathrm{~s}^{-1}$ for August and June, respectively. The change in daily maximum net $\mathrm{CO}_{2}$ uptake with PPFD showed strong seasonal variation with successively increasing daily 'apparent' quantum yields from winter to autumn (Fig. 9b). Daily mean net $\mathrm{CO}_{2}$ uptake by the $\mathrm{T}_{\mathrm{E}} \mathrm{C}_{\mathrm{A}}$ tree reached maximal levels at VPDs between 1.0 and $1.5 \mathrm{kPa}$ (Fig. 9c) and air temperatures of $17-18{ }^{\circ} \mathrm{C}$ (Fig. 9d).

\section{DISCUSSION}

The WTC system demonstrated a good level of control over the growth environment of enclosed trees and an ability to provide tree-level physiological data. The system addresses the pressing need to conduct long-term climate change experiments on mature trees (Saxe et al. 1998, 2001; Norby et al. 1999). In particular, the WTCs allow the study of large, field-grown trees responses to climate change in the long term. The closed-top nature of the WTCs provides for the continuous measurement of tree gas exchange and precise control over air temperature and 
$\left[\mathrm{CO}_{2}\right]$. This is a unique feature of the WTC system, as other systems are designed for long-term treatment rather than for combination with measurements of whole-tree gas exchange. As noted by Kellomäki et al. (2000), the main drawback of WTCs is the large cost associated with their design, construction and operation. In our opinion there is, however, no alternative to such an investment in terms of equipment and running costs required for longterm controlled manipulation experiments to examine the physiological and growth responses of large trees to climate change.

The WTC system was able to maintain set targets of $\left[\mathrm{CO}_{2}\right]$ and air temperature within each chamber on a continuous basis. The energy cost associated with the accurate control of WTC air temperature is high, but an advantage of closed-top WTCs is that most of the air is recirculated, thus reducing the cost of $\mathrm{CO}_{2}$ additions. The $\left[\mathrm{CO}_{2}\right]$ of the $\mathrm{C}_{\mathrm{A}}$ WTCs were approximately $+20 \mu \mathrm{mol} \mathrm{mol}^{-1}$ above the target of $365 \mu \mathrm{mol} \mathrm{mol}^{-1}$ during the 2 -week winter assessment period (Table 2). This was caused by the addition of ambient air to the chambers that had a $\left[\mathrm{CO}_{2}\right]$ greater than target value of $365 \mu \mathrm{mol} \mathrm{mol}^{-1}$. In retrospect it can be concluded that to be able to control the target value of $\left[\mathrm{CO}_{2}\right]$ in $\mathrm{C}_{\mathrm{A}}$ WTCs during winter, and to compensate for nighttime respiration during summer, the target $\left[\mathrm{CO}_{2}\right]$ should not have been the current annual mean of $365 \mu \mathrm{mol} \mathrm{mol}^{-1}$, but $20 \mu \mathrm{mol} \mathrm{mol}^{-1}$ higher, which is close to the annual fluctuations of $\left[\mathrm{CO}_{2}\right]$ in high northern latitudes (Keeling, Chin \& Whorf 1996). An alternative approach would be to alter the system setup so that the $\left[\mathrm{CO}_{2}\right]$ of the $\mathrm{C}_{\mathrm{A}}$ WTCs tracks ambient air, rather than being controlled to a fixed $\left[\mathrm{CO}_{2}\right]$. We do not consider the deviation of $20 \mu \mathrm{mol} \mathrm{mol}^{-1}$ above the target $(<10 \%)$, which occurred during a period of tree dormancy, to carry any significant physiological consequences for the trees inside the $\mathrm{C}_{\mathrm{A}}$ WTCs. Control over $\left[\mathrm{CO}_{2}\right]$ inside $\mathrm{C}_{\mathrm{A}}$ WTCs was improved during the spring assessment period when lower ambient $\left[\mathrm{CO}_{2}\right]$ and tree uptake of $\mathrm{CO}_{2}$ permitted better control by the WTC system. Incursions over the set $\left[\mathrm{CO}_{2}\right]$ of $365 \mu \mathrm{mol} \mathrm{mol}^{-1}$ were generally confined to night time when tree respiration rates exceeded tree $\mathrm{CO}_{2}$ uptake rates. The $\mathrm{C}_{\mathrm{E}}$ WTCs displayed precise and accurate control over $\left[\mathrm{CO}_{2}\right]$, particularly during the winter assessment period. The ability of the system to maintain tight control over $\left[\mathrm{CO}_{2}\right]$ can be attributed to the high frequency of WTC $\left[\mathrm{CO}_{2}\right]$ measurement (every $90 \mathrm{~s}$ ) and the injection of $\mathrm{CO}_{2}$ directly into the circulating air stream from the cooling unit. This facilitated good mixing of the $\mathrm{CO}_{2}$ and prevented vertical $\left[\mathrm{CO}_{2}\right]$ gradients from developing. The maintenance of set $\left[\mathrm{CO}_{2}\right]$ is a vital element of any climate change experiment where $\mathrm{CO}_{2}$ is included. In this regard, the WTC system has provided reliable and accurate control.

A lack of temperature control has been a major limitation of many approaches used for exposure of plants to elevated $\left[\mathrm{CO}_{2}\right]$ (cf. Saxe et al. 1998). Approaches such as branch bags (e.g. Barton et al. 1993; Kellomäki \& Wang 1997) and open-top chambers (e.g. Whitehead et al. 1995; Vapaavuori et al. 2002) have been hampered by uncontrolled temperature increases and the confounding effect they have on the tree responses to the primary variable of interest, for example $\left[\mathrm{CO}_{2}\right]$. The design of the WTC system overcomes this problem by providing a high degree of temperature control. In addition, this system offers controlled temperature elevation, allowing important insights into the interactive effects of $\left[\mathrm{CO}_{2}\right]$ and temperature on tree functioning. At Flakaliden, a high level of temperature control in the spring assessment period was demonstrated with target temperatures inside both the ambient and $\mathrm{T}_{\mathrm{E}}$ WTCs within $\pm 0.5^{\circ} \mathrm{C}$ for $>89 \%$ of the time. This level of control is an improvement on other closed-top chamber systems (Kellomäki et al. 2000; Urban et al. 2001). Temperature control was reduced during the winter because of a deliberate reduction in the cooling capacity of the refrigeration unit. The Flakaliden site is characterized by extremely low winter temperatures (below $-30^{\circ} \mathrm{C}$ ). The accompanying lack of air humidity would have caused an excessive workload and possible damage to the refrigeration unit if full capacity had been maintained during this period. The reduction in cooling capacity during the winter season would not be necessary in warmer climates. Despite the reduction in capacity, the WTC temperatures during the winter assessment period were within \pm 2 and $\pm 1^{\circ} \mathrm{C}$ of the target temperature in the ambient and $\mathrm{T}_{\mathrm{E}}$ WTCs, respectively. Short day lengths and low incident light levels during the winter at Flakaliden also minimized radiation warming inside the WTCs. The precise nature of the temperature control for the WTC system gives confidence in the ability of the system to reproduce the temperature conditions outside the WTCs and provides the basis for a realistic assessment of the responses of trees to climate change.

Any air humidity changes caused by tree chambers can affect the stomatal function and transpiration patterns of an enclosed conifer tree more than changes in $\left[\mathrm{CO}_{2}\right]$ (cf. Medlyn et al. 2001). The WTC system was able to respond quickly to changes in reference air vapour pressure and this fast response time, coupled with the large capacity of the cooling system meant that the vapour pressure of the WTC air was generally the same as that of the reference air (cf. Fig. 6). This meant that the moisture generated by the transpiring tree inside each WTC was condensed from the system rapidly enough so as not to cause feedback influences on transpiration rates. By virtue of the fact that all 12 WTCs were maintained at the same vapour pressure as reference air, the VPD of $T_{E}$ WTCs was greater than that of the reference air and the $\mathrm{T}_{\mathrm{A}}$ WTCs. The decision to maintain all WTCs at reference air VPD was made for two reasons. Firstly, to run the ambient and $\mathrm{T}_{\mathrm{E}}$ WTCs at identical VPD would have required two separate cooling systems. For logistical and financial reasons, this was not a feasible option. Secondly, the possibility of increased surface temperatures and potential evaporation not being matched by increased precipitation in some regions has been shown with some global climate change models (Cubasch et al. 2001). We acknowledge, however, that greater VPD in the elevated WTCs may influence the interactions between 
$\left[\mathrm{CO}_{2}\right]$ and temperature for some physiological processes. It is worth noting that a study on the stable $\delta^{13} \mathrm{C}$ of the WTC trees at Flakaliden found no difference in the $\delta^{13} \mathrm{C}$ of needle soluble sugars, starch and bulk material of $\mathrm{T}_{\mathrm{A}} \mathrm{C}_{\mathrm{A}}$ and $\mathrm{T}_{\mathrm{E}} \mathrm{C}_{\mathrm{A}}$ trees (Comstedt et al. 2006). This result suggests that the VPD disparity between $\mathrm{T}_{\mathrm{A}}$ and $\mathrm{T}_{\mathrm{E}}$ treatments had no major effect on stomatal behaviour. This is supported by the similar $\delta^{13} \mathrm{C}$ of $\mathrm{T}_{\mathrm{A}} \mathrm{C}_{\mathrm{A}}$ and $\mathrm{T}_{\mathrm{E}} \mathrm{C}_{\mathrm{A}}$ wood rings laid down during the course of the experiment (Marshall J., University of Idaho, unpublished results).

The transmittance of radiation through the plastic material of the WTC walls was similar to that reported for other chamber systems (e.g. Whitehead et al. 1995; Kellomäki et al. 2000; Vapaavuori et al. 2002). The decline in radiation transmission with age of plastic was less than that observed by Whitehead et al.(1995), despite a greater plastic age and a harsher climate, in terms of temperature fluctuations in the present study. The reduction in PPFD entering the WTCs was, on average, $21 \%$ throughout a 6 month period. The difference between the measured reduction in transmittance of the plastic (16\%) and the PPFD measured reduction was probably a result of the reflectance and shade from the frame of the WTCs. The aluminium structural components of the WTCs would be expected to cause a degree of shading inside the WTC. The shading effect of each WTC frame changed throughout the course of the day and within season with changing solar angles. The cooling units of each WTC were positioned to minimize shading of both the tree inside the WTC and other nearby WTCs.

There was minimal effect of the WTC structure on the behaviour of the enclosed trees for a range of physiological parameters and structural characteristics (cf. Table 4). There were significant differences in timing of bud burst between $\mathrm{R}$ and $\mathrm{T}_{\mathrm{A}} \mathrm{C}_{\mathrm{A}}$ trees in 2002 and 2004, but not in 2003 (Slaney et al. in review). The difference between WTCs and $\mathrm{R}$ trees in timing of bud burst was attributed to the WTCs reducing the risk of radiation frosts each year, both as an effect of the plastic cover and the continuous air movement in the WTCs (approximately $0.5 \mathrm{~m} \mathrm{~s}^{-1}$ ). The variation in WTC effect on bud break between years has been attributed to the differences in the number and intensity of radiation frosts each year (Slaney et al. in review). The reduction in PPFD levels $(21 \%)$ inside the WTC is likely to reduce the level of photoinhibitory damage to the photosynthetic apparatus sustained by the needles during the period of spring photosynthetic recovery. The $\delta^{13} \mathrm{C}$ of wood rings provides a long-term indication of treatment-driven changes in stomatal conductance and/or intercellular $\left[\mathrm{CO}_{2}\right]$. The similar $\delta^{13} \mathrm{C}$ of wood rings in the $\mathrm{T}_{\mathrm{A}} \mathrm{C}_{\mathrm{A}}$ and $\mathrm{R}$ trees (Table 4) suggests that the WTCs did not alter needle anatomy or physiology. The observed difference in $\delta^{13} \mathrm{C}$ of needle bulk material between $\mathrm{T}_{\mathrm{A}} \mathrm{C}_{\mathrm{A}}$ and $\mathrm{R}$ trees was probably a result of the fact that the isotopic composition of the source $\mathrm{CO}_{2}$ of the $\mathrm{C}_{\mathrm{A}}$ chambers (bottled $\mathrm{CO}_{2}$ ) was depleted $(-10.4 \%$ o compared with air outside the chambers $(-8 \%$ o $)$ (Comstedt et al. 2006). Kellomäki et al. (2000) reported significant chamber effects on some physiological parameters for their closed $\mathrm{CO}_{2}$ and temperature-controlled cham- ber system used on field-grown Scots pine (Pinus sylvestris L.). They attributed these differences to the $34-45 \%$ reduction in PPFD levels in the chambers (Kellomäki et al. 2000). The PPFD reduction in the present study was less than this range (21\% averaged across 6 months), which may explain why significant differences were not observed.

The measurement of the gases entering and leaving the WTCs and their closed-top nature allows the WTCs to be treated as large cuvettes and the tree-level fluxes of $\mathrm{CO}_{2}$ and water to be calculated. To the best of our knowledge, this paper presents the first results of the annual time course of $\mathrm{CO}_{2}$ fluxes for the above-grown portion of a fieldgrown tree. Drawing conclusions from the physiological data presented in the present paper is beyond the scope of the discussion as data is presented to illustrate the performance and potential use of the WTC system rather than drawing definitive conclusions regarding the impact of elevated temperature and $\left[\mathrm{CO}_{2}\right]$ on boreal Norway spruce trees. Moreover it serves to illustrate the ability of the WTC system to quantify the $\mathrm{CO}_{2}$ flux over an annual time course and overcome the difficulties involved in scaling from discontinuous measurements to tree-level and/or stand estimates (cf. Wallin et al. 2001; Damesin et al. 2002).

There is potential for applying the data from the WTCs to the development and validation of predictive models. In particular, the data has great utility in validating the scaling of shoot-level flux measurements to estimates of tree-level fluxes. Tree-level measurements provide an integration of measurements of individual tree organs such as shoots and stems. For example, the P. abies tree-level $Q_{10}$ value calculated in the present paper was greater than mean values reported for P. abies stems at Flakaliden (Ceschia 2001) and less than that of P.abies needles during winter at Flakaliden (Stockfors \& Linder 1998b). The ability to continuously measure gas fluxes of mature trees is an advantage of the WTC system. The data also allows the physiological behaviour of trees to be examined on a range of temporal scales in response to climatic variation and the calculation of additional useful parameters such as aboveground net primary production.

\section{ACKNOWLEDGMENTS}

The WTCs were an integral part of a project examining the responses of Norway spruce to climate change. This project was funded by the Swedish Council for Planning and Coordination of Research (FRN), the Swedish Council of Forestry and Agricultural Research (SJFR), the Swedish National Energy Administration (STEM), Nils and Dorthi Troëdssons Research Foundation and the European Union through the Environment Research and Development Programme (ECOCRAFT, FORCAST). We thank Bengt-Olof Wigren and Gunnar Karlsson for their invaluable help in the construction and maintenance of the WTC system. We are grateful to Dr John Marshall and Daniel Comstedt for kindly providing stable carbon isotopic composition data. We also thank Dr Chris Beadle for comments on an earlier version of this manuscript. 


\section{REFERENCES}

Allen L.H., Drake B.G., Rogers H.H. \& Shinn J.H. (1992) Field techniques for exposure of plants and ecosystems to elevated $\mathrm{CO}_{2}$ and other trace gases. Critical Reviews in Plant Sciences 11, 85-119.

Barton C.V.M., Lee H.S.J. \& Jarvis P.G. (1993) A branch-bag and $\mathrm{CO}_{2}$ control system for long-term $\mathrm{CO}_{2}$ enrichment of mature Sitka spruce (Picea sitchensis (Bong.) Carr.). Plant, Cell \& Environment 16, 1139-1148.

Bergh J. \& Linder S. (1999) Effects of soil warming during spring on photosynthetic recovery in boreal Norway spruce stands. Global Change Biology 5, 245-253.

Bergh J., Linder S., Lundmark T. \& Elfving B. (1999) The effect of water and nutrient availability on the productivity of Norway spruce in northern and southern Sweden. Forest Ecology and Management 119, 51-62.

Burroughs W.J. (2001) Climate Change - a Multidisciplinary Approach. Cambridge University Press, New York, NY, USA.

Ceschia E. (2001) Environmental effects on spatial and seasonal variations of stem respiration in European beech and Norway spruce. Acta Universitatis Agriculturae Sueciae, Silvestria 219, Doctoral Thesis. 58 pp. ISBN 91-576-6303-3.

Christensen J.H., Räisänen J., Iverson T., Bjørge D., Christensen O.B. \& Rummukainen M. (2001) A synthesis of regional climate change simulations - a Scandanavian perspective. Geophysical Research Letters 28, 1003-1006.

Comstedt D., Boström B., Marshall J.D., Holm A., Slaney M., Linder S. \& Ekblad A. (2006) Effects of elevated $\left[\mathrm{CO}_{2}\right]$ and temperature on soil respiration in a boreal forest using $\delta^{13} \mathrm{C}$ as a labelling tool. Ecosystems In press.

Cubasch U., Meehl G., Boer G., Stouffer M., Dix A., Noda C., Senior S., Raper S. \& Yap K. (2001) Projections of future climate change. In Climate Change 2001: the Scientific Basis. Contribution of Working Group I to the Third Assessment Report of the Intergovernmental Panel on Climate Change (eds J. Houghton, Y. Ding, D. Griggs, M. Noguer, P. van der Linden, X. Dai, K. Maskell \& C. Johnson), pp. 525-582. Cambridge University Press, Cambridge, UK.

Curtis P.S. (1996) A meta-analysis of leaf gas exchange and nitrogen in trees grown under elevated carbon dioxide. Plant, Cell \& Environment 19, 127-137.

Damesin C., Ceschia E., Le Goff N., Ottorini J.-M. \& Dufrêne E. (2002) Stem and branch respiration of beech: from tree measurements to estimations at the stand level. New Phytologist 153, $159-172$.

Drake B.G., Gonzàlez-Meler M.A. \& Long S.P. (1997) More efficient plants: a consequence of rising atmospheric $\mathrm{CO}_{2}$ ? Annual Review of Plant Physiology and Plant Molecular Biology 48, 609-639.

Fransson P.M.A., Taylor A.F.S. \& Finlay R.D. (2001) Elevated atmospheric $\mathrm{CO}_{2}$ alters root symbiont community structure in forest trees. New Phytologist 152, 431-442.

Hamilton J.G., Thomas R.B. \& DeLucia E.H. (2001) Direct and indirect effects of elevated $\mathrm{CO}_{2}$ on leaf respiration in a forest ecosystem. Plant, Cell \& Environment 24, 975-982.

Hendrey G.R., Ellsworth D.S., Lewin K.F. \& Nagy J. (1999) A free-air enrichment system for exposing tall forest vegetation to elevated atmospheric $\mathrm{CO}_{2}$. Global Change Biology 5, 293309.

Herrick J.D. \& Thomas R.B. (2001) No photosynthetic downregulation in sweetgum trees (Liquidambar styraciflua $\mathrm{L}$.) after three years of $\mathrm{CO}_{2}$ enrichment at the Duke Forest FACE experiment. Plant, Cell \& Environment 24, 53-64.

IPCC (2001) Climate Change 2001: the Scientific Basis. Contribution of Working Group 1 to the Third Assessment Report of the
Intergovernmental Panel on Climate Change. Cambridge University Press, Cambridge, UK and New York, NY, USA.

Jach M.E. \& Ceulemans R. (1999) Effects of elevated atmospheric $\mathrm{CO}_{2}$ on phenology, growth and crown structure of Scots pine (Pinus sylvestris) seedlings after two years of exposure in the field. Tree Physiology 19, 289-300.

Keeling C.D., Chin J.F.S. \& Whorf T.P. (1996) Increased activity of northern vegetation inferred from atmospheric $\mathrm{CO}_{2}$ measurements. Nature 382, 146-149.

Kellomäki S. \& Wang K.Y. (1997) Photosynthetic responses of Scots pine to elevated $\mathrm{CO}_{2}$ and nitrogen supply: results of a branch-in-bag experiment. Tree Physiology 17, 231-240.

Kellomäki S., Wang K. \& Lemettinen M. (2000) Controlled environment chambers for investigating tree response to elevated $\mathrm{CO}_{2}$ and temperature under boreal conditions. Photosynthetica 38, 69-81.

Körner C. (2003) Carbon limitation in trees. Journal of Ecology 91, 4-17.

Körner C., Asshoff R., Bignucolo O., Hättenschwiler S., Keel S.G., Peláez-Riedl S., Pepin S., Siegwold R.T.W. \& Zotz G. (2005) Carbon flux and growth in mature deciduous forest trees exposed to elevated $\mathrm{CO}_{2}$. Science 309, 1360-1362.

Kostiainen K., Kaakinen S., Saranpää P., Linder S., Sigurdsson B. \& Vapaavuori E. (2004) Effect of elevated $\left[\mathrm{CO}_{2}\right]$ on stem wood properties of mature Norway spruce grown at different soil nutrient availability. Global Change Biology 10, 15261538.

Linder S. (1995) Foliar analysis for detecting and correcting nutrient imbalances in Norway spruce. Ecological Bulletins (Copenhagen) 44, 178-190.

Liozon R., Badeck F.-W., Genty B., Meyer S. \& Saugier B. (2000) Leaf photosynthetic characteristics of beech (Fagus sylvatica) saplings during three years of exposure to elevated $\mathrm{CO}_{2}$ concentration. Tree Physiology 20, 239-247.

Luo Y., Su B., Currie W.S., et al. (2004) Progressive nitrogen limitation of ecosystem responses to rising atmospheric carbon dioxide. Bioscience 54, 731-740.

Medlyn B.E., Barton C.V.M., Broadmeadow M.S.J., et al. (2001) Stomatal conductance of forest species after long-term exposure to elevated $\mathrm{CO}_{2}$ concentration: a synthesis. New Phytologist 149, 247-264.

Murray M.B., Smith R.I., Friend A. \& Jarvis P.G. (2000) Effect of elevated $\left[\mathrm{CO}_{2}\right]$ and varying nutrient application rates on physiology and biomass accumulation of Sitka spruce (Picea sitchensis). Tree Physiology 20, 421-434.

Norby R.J. \& Luo Y. (2004) Evaluating ecosystem responses to rising atmospheric $\mathrm{CO}_{2}$ and global warming in a multi-factor world. New Phytologist 162, 281-293.

Norby R.J., Wullschleger S.D., Gunderson C.A., Johnson D.W. \& Ceulemans R. (1999) Tree responses to rising $\mathrm{CO}_{2}$ in field experiments: implications for the future forest. Plant, Cell \& Environment 22, 683-714.

Räisänen J. \& Joelsson R. (2001) Changes in average and extreme precipitation in two regional climate model experiments. Tellus 53A, 547-566.

Räisänen J., Rummukainen M. \& Ullerstig A. (2001) Downscaling of greenhouse gas induced climate change in two GCMs with the Rossby Centre regional climate model for northern Europe. Tellus 53A, 168-191.

Robertnz P. (1999) Effects of long-term $\mathrm{CO}_{2}$ enrichment and nutrient availability in Norway spruce. I. Phenology and morphology of branches. Trees 13, 188-198.

Robertnz P. \& Stockfors J. (1998) Effects of elevated $\mathrm{CO}_{2}$ concentration and nutrition on net photosynthesis, stomatal conductance and needle respiration of field-grown Norway spruce trees. Tree Physiology 18, 233-241. 
Saugier B., Granier A., Pontailler J.Y., Dufrêne E. \& Baldocchi D.D. (1997) Transpiration of a boreal pine forest measured by branch bag, sap flow and micrometeorological methods. Tree Physiology 17, 511-519.

Saxe H., Ellsworth D.S. \& Heath J. (1998) Tree and forest functioning in an enriched $\mathrm{CO}_{2}$ atmosphere. New Phytologist 139, 395-436.

Saxe H., Cannell M.G.R., Johnsen Ø., Ryan M.G. \& Vourlitis G. (2001) Tree and forest functioning in response to global warming. New Phytologist 149, 369-400.

Slaney M. (2006) Impact of elevated temperature and $\left[\mathrm{CO}_{2}\right]$ on spring phenology and photosynthetic recovery of boreal Norway spruce. Doctoral Thesis. Acta Universitatis Agriculturae Sueciae.

Slaney M., Wallin G., Medhurst J. \& Linder S. (in review) Impact of elevated $\mathrm{CO}_{2}$ and temperature on spring phenology of boreal Norway spruce. Tree Physiology In press.

Stockfors J. \& Linder S. (1998a) Effect of nitrogen on the seasonal course of growth and maintenance respiration in stems of Norway spruce trees. Tree Physiology 18, 155-166.

Stockfors J. \& Linder S. (1998b) The effect of nutrition on the seasonal course of needle respiration in Norway spruce stands. Trees 12, 130-138.
Urban O., Janouš D., Pokorný R., Marková I., Pavelka M., Fojtík Z., Šprtová M., Kalina J. \& Marek M.V. (2001) Glass domes with adjustable windows: a novel technique for exposing juvenile forest stands to elevated $\mathrm{CO}_{2}$ concentration. Photosynthetica 39, 395-401.

Vapaavuori E., Oksanen T., Holopainen J.K., et al. (2002) OpenTop Chamber Fumigation of Cloned Silver Birch (Betula Pendula Roth) Trees to Elevated CO2 and Ozone: Description of the Fumigation System and the Experimental Site. Research Papers 838, pp. 28. The Finnish Forest Research Institute, Joensuu, Finland.

Wallin G., Linder S., Lindroth A., Räntfors M., Flemberg S. \& Grelle A. (2001) Carbon dioxide exchange in Norway spruce at the shoot, tree and ecosystem scale. Tree Physiology 21, 969976.

Whitehead D., Hogan K.P., Rogers G.N.D., Byers J.N., Hunt J.E., McSeveny T.M., Hollinger D.Y., Dungan R.J., Earl W.B. \& Bourke M.P. (1995) Performance of large open-top chambers for long-term field investigations of tree response to elevated carbon dioxide concentration. Journal of Biogeography 22, 307313.

Received 14 December 2005; accepted for publication 5 May 2006

\section{APPENDIX I}

\begin{tabular}{lll}
\hline Component & Description & Manufacturer \\
\hline Chamber wall & 0.4 mm transparent PVC film & Renolit AG, Germany, <http://www.renolit.com> \\
Chamber base circulation fan & Model TD-160 & Soler \& Palau, Spain, <soler-palau.com> \\
Soil moisture sensor & Thetaprobe ML1 & Delta-T Devices Ltd. UK, <http://www.delta-t.co.uk> \\
Safety ventilation system motor & Model SM24 & Belimo, Switzerland, <http://www.belimo.com> \\
Safety ventilation system diesel generator & Model YDG 3700E-E & Yanmar, Japan, <http://www.yanmar.co.jp> \\
Cooling unit circulating fan & LPMA 6-060 & Swegon, Sweden, <http://www.swegon.com> \\
Regulating iris for fresh air inlet & IRIS-125 & REC-Indovent AB, Sweden, <http://www.rec-indovent.se> \\
Differential air pressure sensor & Model LP & Honeywell, Data Instruments, USA, \\
& & $<$ http://www.honeywell.com> \\
Main $\mathrm{CO}_{2}$ line pressure regulator & Model 8624 & Bürkert, Germany, <http://www.burkert.com> \\
Chamber infrared CO $\mathrm{C}_{2}$ gas analyser & SBA-1 & PP Systems, UK, <http://www.ppsystems.com> \\
Chamber $\mathrm{CO}_{2}$ injection magnetic valve & Model 6011 & Bürkert, Germany, <http://www.burkert.com> \\
Chamber $\mathrm{CO}_{2}$ mass flow meter & AWM3000; AWM5000 & Honeywell, USA, <http://www.honeywell.com> \\
Flow calibrator & DryCal DC-1 & Bios International, USA, <http://www.drycal.com> \\
Central infrared $\mathrm{CO}_{2}$ gas analysers & CIRAS-2 DC; WBA-2 & PP Systems, UK, <http://www.ppsystems.com> \\
Quantum sensor & LI-190SA & Li-Cor Inc., USA, <http://www.licor.com> \\
Cooling unit damper actuator & ASU1d15 & Staefa Control, USA, <http://www.staefacontrol.com> \\
I/O modules \& converter & SIOX S12; K30 RS232C-SIOX & Telefrang AB, Sweden, <http://www.telefrang.se> \\
Sample gas magnetic valve control system & M-331-c-04 & Bürkert, Germany, <http://www.burkert.com> \\
\hline
\end{tabular}

